\title{
Construction of Sequence-Regulated Vinyl Copolymers via Iterative Single Vinyl Monomer Additions and Subsequent Metal-Catalyzed Step-Growth Radical Polymerization
}

\author{
Kotaro Satoh, Kenta Ishizuka, Tsuyoshi Hamada, Masato Handa, Tomohiro Abe, Satoshi Ozawa, \\ Masato Miyajima, and Masami Kamigaito*
}

Department of Molecular and Macromolecular Chemistry, Graduate School of Engineering, Nagoya University, Nagoya 464-8603, Japan

e-mail:satoh@chambio.nagoya-u.ac.jp,kamigait@chambio.nagoya-u.ac.jp

\section{Contents:}

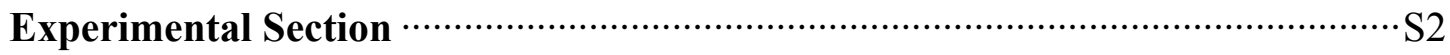

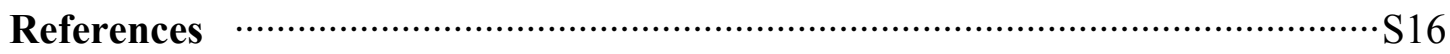

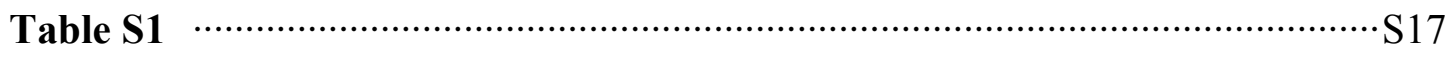

Table S2

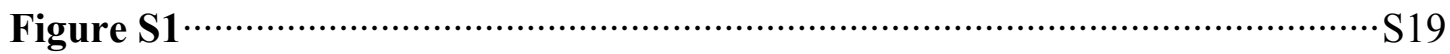

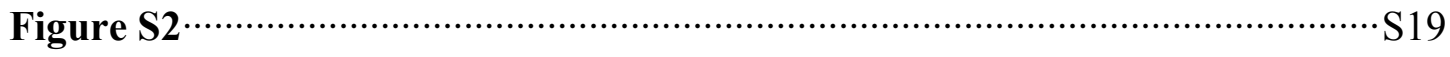

Figure S3

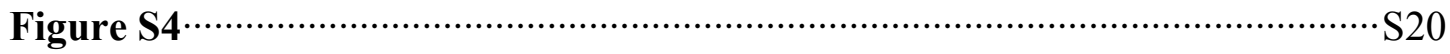

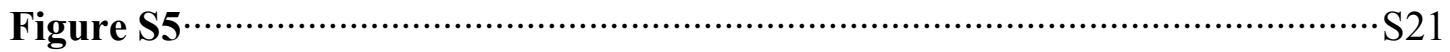

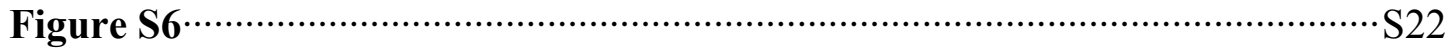

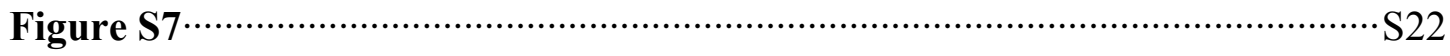

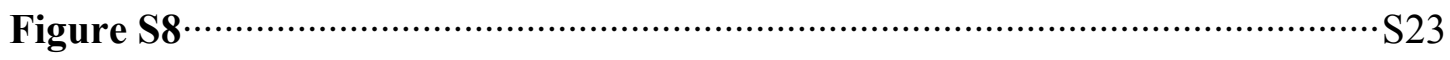

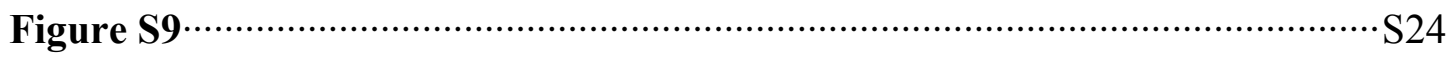

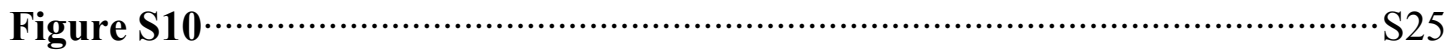

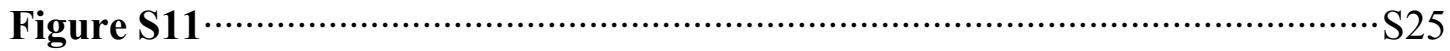




\section{Experimental Section}

Materials. Methyl acrylate (Tokyo Kasei, >99\%), styrene (Kishida, 99.5\%), p-methylstyrene (Wako, >95\%), acrylonitrile (Kishida, 98\%), 1,8-nonadiene (VEEV) (Tokyo Kasei, >98\%), methyl dichloroacetate $\left(\mathrm{ClA}_{\mathbf{M}} \mathrm{Cl}\right)$ (Tokyo Kasei, >99\%), ethyl dichloroacetate $\left(\mathrm{ClA} \mathrm{E}_{\mathrm{E}} \mathrm{Cl}\right)$ (Merck, $\left.>98 \%\right), \quad \alpha, \alpha$-dichlorotoluene (ClSCl) (Tokyo Kasei, $>95 \%$ ), dichloroacetonitrile $\left(\mathrm{ClNCl}\right.$ ) (Tokyo Kasei, $>98 \%$ ), $\mathrm{CCl}_{4}$ (Wako, $>99.5 \%$ ), allyltrimethylsilane (Tokyo Kasei, >98\%), $N, N, N$, $N$ ', $N$ ',-pentamethyldiethylenetriamine (PMDETA) (Aldrich, $>99 \%$ ) 1,1,4,7,10,10-hexamethyltriethylenetetramine (HMTETA) (Aldrich, 97\%), tris[2-(dimethylamino)ethyl]amine (Me $\left.{ }_{6} \mathrm{TREN}\right)$ (Aldrich, 97\%), tributylphosphine (Kanto, $>98 \%$ ), chlorobenzene (Kishida, 99.5\%), $n$-octane (Tokyo Kasei, >97\%), and $N, N$-dimethylformamide (Kanto, $>99.5 \%$ ) were distilled over calcium hydride under reduced or atmospheric pressure before use. $\quad \mathrm{RuCl}_{2}\left(\mathrm{PPh}_{3}\right)_{3}$ (Aldrich, 97\%), $\mathrm{RuCp} * \mathrm{Cl}\left(\mathrm{PPh}_{3}\right)_{2}$ (provided from Wako, 99\%), $\mathrm{CuCl}$ (Aldrich, 99.99\%), $\mathrm{CuCl}_{2}$ (Aldrich, 99.995\%), $\mathrm{FeCl}_{2}$ (Aldrich, 99.99\%), 2,2'-bipyridyl (bpy) (Aldrich, >99\%), 4,4'-dinonyl-2,2'-bipyridyl (dNbpy) (Aldrich, 97\%), and $n \mathrm{Bu}_{4} \mathrm{NCl}$ (Furuka, $>97 \%$ ) were used as received and handled in a glove box (MBRAUN LABmaster sp) under a moisture- and oxygen-free argon atmosphere $\left(\mathrm{O}_{2},<1 \mathrm{ppm}\right.$ ). Toluene (Kanto, $>99.5 \% ; \mathrm{H}_{2} \mathrm{O}<10$ ppm), $\mathrm{CH}_{2} \mathrm{Cl}_{2}$ (Kanto, $>99.5 \%, \mathrm{H}_{2} \mathrm{O}<20 \mathrm{ppm}$ ), methylcyclohexane (Kanto, $>98 \%$ ), and tetrahydrofuran (Kanto, $>99.5 \%$ ) were dried and deoxygenized by passage through columns from Glass Contour Solvent Systems before use. Allylmagnesium chloride (Aldrich, $2 \mathrm{M}$ in THF), dimethylamine (Tokyo Kasei, $2 \mathrm{M}$ in methanol), n-propylamine (Tokyo Kasei, >98\%), isopropylamine (Tokyo Kasei, >99\%), ethanolamine (Tokyo Kasei, >99\%), $\mathrm{ZnCl}_{2}$ (Aldrich, 1.0 $\mathrm{M}$ in $\mathrm{Et}_{2} \mathrm{O}$ ), $\mathrm{TiCl}_{4}$ (Kojundo Chemical Laboratory, Co., Ltd., 99.999\%), and $\mathrm{SnCl}_{4}$ (Aldrich, 99.995\%) were used as received and handled under dry nitrogen. $\mathrm{VSA}_{\mathbf{M}} \mathbf{A}_{\mathbf{M}} \mathrm{Cl}$ was synthesized according to the literature. ${ }^{1}$

Synthesis of CINNCl. $\mathrm{CuCl}(0.792 \mathrm{~g}, 8.00 \mathrm{mmol})$, bpy (10.0 g, $64.0 \mathrm{mmol})$, toluene (26.1 $\mathrm{mL}$ ), acrylonitrile $(105 \mathrm{~mL}, 1.60 \mathrm{~mol})$, and dichloroacetonitrile $(\mathrm{ClNCl})(257 \mathrm{~mL}, 3.20 \mathrm{~mol})$ were placed in a $500 \mathrm{~mL}$ round-bottomed flask under dry nitrogen at room temperature $\left([\mathrm{ClNCl}]_{0} /[\text { acrylonitrile }]_{0} /[\mathrm{CuCl}]_{0} /[\mathrm{bpy}]_{0}=8000 / 4000 / 20 / 160 \mathrm{mM}\right.$, total volume: $\left.400 \mathrm{~mL}\right)$. The flask was placed in an oil bath at $80^{\circ} \mathrm{C}$ under vigorous stirring. The conversion of acrylonitrile was determined by measuring the vinyl group of the residual acrylonitrile by ${ }^{1} \mathrm{H}$ NMR. After 70 $\mathrm{h}$, the conversion of acrylonitrile reached $85 \%$ to form $\mathrm{ClNNCl}$ in high yield $(81 \%)$. The 
solution was diluted with $\mathrm{Et}_{2} \mathrm{O}$ and washed twice with aqueous $\mathrm{HCl}$ and then twice with water. The organic layer was evaporated to remove the solvents and the remaining CINCl. The product $(\mathrm{ClNNCl})$ was distilled under reduced pressure $\left(25 \mathrm{~Pa}\right.$, bp. $\left.65{ }^{\circ} \mathrm{C}\right)$ to give a colorless liquid (160 g, $0.982 \mathrm{mmol}$, yield $=61 \%$ based on acrylonitrile, purity $>99.6 \%, d=1.20) . \quad{ }^{1} \mathrm{H}$ $\operatorname{NMR}\left(\mathrm{CDCl}_{3}, 25^{\circ} \mathrm{C}\right): \delta 2.74-2.92\left(\mathrm{~m}, \mathrm{CH}_{2}-\mathrm{CH}\right), 4.71-4.77\left(\mathrm{~m}, \mathrm{CH}-\mathrm{CH}_{2}\right)$ (Figure 4A).

Synthesis of $\mathbf{V S}_{\mathbf{M}} \mathbf{N N C l}$. $\mathrm{CuCl}(0.246 \mathrm{~g}, 2.48 \mathrm{mmol})$, bpy (1.16 g, $\left.7.43 \mathrm{mmol}\right)$, p-methylstyrene $(32.5 \mathrm{~mL}, 247 \mathrm{mmol})$, and ClNNCl $(90.0 \mathrm{~mL}, 663 \mathrm{mmol})$ were placed in a 200 $\mathrm{mL}$ round-bottomed flask under dry nitrogen at room temperature $\left([\mathrm{ClNNCl}]_{0} /[p \text {-methylstyrene }]_{0} /[\mathrm{CuCl}]_{0} /[\mathrm{bpy}]_{0}=5340 / 2000 / 20 / 60 \mathrm{mM}\right.$, total volume: $\left.124 \mathrm{~mL}\right)$. The flask was placed in an oil bath at $80{ }^{\circ} \mathrm{C}$ under vigorous stirring. The conversion of $p$-methylstyrene was determined by measuring the vinyl group of the residual $p$-methylstyrene by ${ }^{1} \mathrm{H}$ NMR. After $1.5 \mathrm{~h}$, the conversion of $p$-methylstyrene reached $96 \%$ to form $\mathrm{ClS}_{\mathbf{M}} \mathbf{N N C l}$ in high yield (87\%). The solution was diluted with $\mathrm{Et}_{2} \mathrm{O}$ and washed three times with aqueous $\mathrm{HCl}$ and then three times with water. The organic layer was evaporated to remove the solvents, and was purified by a silica-gel column eluted with $n$-hexane/EtOAc (1/1), and was evaporated to yield a pale yellow liquid (140 g) containing $\mathrm{ClS}_{\mathbf{M}} \mathbf{N N C l}$ and unreacted $\mathrm{ClNNCl}$.

The liquid was then put into a $1 \mathrm{~L}$ round-bottomed flask, into which $\mathrm{CH}_{2} \mathrm{Cl}_{2}(120 \mathrm{~mL})$ and allyltrimethylsilane $(120 \mathrm{~mL}, 756 \mathrm{mmol})$ were added at room temperature. After the solution was cooled to $0{ }^{\circ} \mathrm{C}, 1.0 \mathrm{M} \mathrm{ZnCl}_{2}$ solution $\left(100 \mathrm{~mL}\right.$ in $\left.\mathrm{Et}_{2} \mathrm{O}, 100 \mathrm{mmol}\right)$ was slowly added $\left(\left[\mathrm{ClS}_{\mathbf{M}} \mathbf{N N C l}\right]_{0} /[\text { allyltrimethylsilane }]_{0} /\left[\mathrm{ZnCl}_{2}\right]_{0}=0.51 / 1.6 / 0.21 \mathrm{M}\right.$, total volume: $480 \mathrm{~mL}$; The concentration of $\mathrm{ClS}_{\mathbf{M}} \mathbf{N N C l}$ is the theoretical value based on $100 \%$ yield of $\mathrm{ClS}_{\mathbf{M}} \mathbf{N N C l}$.). After the mixture was stirred for $19 \mathrm{~h}$ at room temperature, ammonia methanol $(100 \mathrm{~mL})$ was added slowly over $30 \mathrm{~min}$ to quench the reaction. The solution was diluted with toluene $(400 \mathrm{~mL})$ and washed three times with aqueous $\mathrm{Na}_{4}$ EDTA, three times with aqueous $\mathrm{NaOH}$, and three times with water. The organic layer was evaporated to remove the solvents and was passed through silica-gel, neutral alumina, and basic alumina columns with $n$-hexane/Et ${ }_{2} \mathrm{O}(1 / 1)$. The solvents were evaporated, and the remaining liquid was treated with activated carbon and then an absorbent [Kyowaad-2000G-7 $\left(\mathrm{Mg}_{0.7} \mathrm{Al}_{0.3} \mathrm{O}_{1.15}\right)$; Kyowa Chemical] to remove the metal residues. The treated solution was purified by a silica-gel column eluted with $n$-hexane/Et ${ }_{2} \mathrm{O}(1 / 1)$ to remove the remaining $\mathrm{ClNNCl}$. After evaporation of the solvents, the crude product was obtained $(18.9 \mathrm{~g})$. The product $\left(\mathrm{VS}_{\mathbf{M}} \mathbf{N N C l}\right)$ was distilled under reduced pressure $(0.02 \mathrm{mmHg}$, 
bp. $\left.99^{\circ} \mathrm{C}\right)$ to give a colorless liquid $(9.06 \mathrm{~g}, 31.6 \mathrm{mmol}$, yield $=12.8 \%$ based on $p$-methylstyrene, $d=1.06) . \quad{ }^{1} \mathrm{H}$ NMR $\left(\mathrm{CDCl}_{3}, 25{ }^{\circ} \mathrm{C}\right): \delta 1.67-2.98(\mathrm{~m}, 12 \mathrm{H}), 4.47-4.60(\mathrm{~m}, \mathrm{CH}-\mathrm{Cl}), 4.97-5.08$ (m, $\left.\mathrm{CH}_{2}=\mathrm{CH}\right), 5.57-5.73\left(\mathrm{~m}, \mathrm{CH}=\mathrm{CH}_{2}\right), 6.99-7.21(\mathrm{~m}, 4 \mathrm{H})$ (Figure $\mathrm{S} 1$ ).

Synthesis of $\mathbf{C l A}_{\mathbf{M}} \mathbf{A}_{\mathbf{M}} \mathbf{C l}$. $\mathrm{RuCl}_{2}\left(\mathrm{PPh}_{3}\right)_{3}(7.67 \mathrm{~g}, 8.00 \mathrm{mmol})$, toluene $(20 \mathrm{~mL})$, methyl acrylate $(144 \mathrm{~mL}, 1.60 \mathrm{~mol})$, and methyl dichloroacetate $\left(\mathrm{Cl} \mathbf{A}_{\mathbf{M}} \mathrm{Cl}\right)(628 \mathrm{~mL}, 6.07 \mathrm{~mol})$ were placed in a $1 \mathrm{~L}$ round-bottomed flask under dry nitrogen at room temperature $\left(\left[\mathrm{Cl} \mathbf{A}_{\mathbf{M}} \mathrm{Cl}\right]_{0} /[\right.$ methyl acrylate $]_{0} /\left[\mathrm{RuCl}_{2}\left(\mathrm{PPh}_{3}\right)_{3}\right]_{0}=7590 / 2000 / 10 \mathrm{mM}$, total volume: $800 \mathrm{~mL}$ ). The flask was placed in an oil bath kept at $80{ }^{\circ} \mathrm{C}$ under vigorous stirring. The conversion of methyl acrylate was determined by measuring the vinyl group of the residual methyl acrylate by ${ }^{1} \mathrm{H}$ NMR. After 57 $\mathrm{h}$, the conversion of methyl acrylate reached $90 \%$ to form mainly $\mathrm{Cl} \mathbf{A}_{\mathbf{M}} \mathbf{A}_{\mathbf{M}} \mathrm{Cl}$. After the precipitation of the ruthenium complex into $n$-hexane, the solution was evaporated to remove the solvents and the remaining $\mathrm{Cl} \mathbf{A}_{\mathbf{M}} \mathrm{Cl}$. The product $\left(\mathrm{Cl} \mathbf{A}_{\mathbf{M}} \mathbf{A}_{\mathbf{M}} \mathrm{Cl}\right)$ was distilled under reduced pressure $\left(2 \mathrm{mmHg}\right.$, bp. $\left.99^{\circ} \mathrm{C}\right)$ to give a colorless liquid $(128 \mathrm{~g}, 558 \mathrm{mmol}$, yield $=35 \%$ based on methyl acrylate, $d=1.37) . \quad{ }^{1} \mathrm{H}$ NMR $\left(\mathrm{CDCl}_{3}, 25{ }^{\circ} \mathrm{C}\right): \delta 2.49-2.87\left(\mathrm{~m}, \mathrm{CH}_{2}-\mathrm{CH}\right), 3.79-3.85(\mathrm{~s}$, $\mathrm{CH}_{3}-\mathrm{O}$ ), 4.46-4.65 (m, $\mathrm{CH}-\mathrm{Cl}$ ) (Figure 4B).

Synthesis of $\mathbf{V S}_{\mathbf{M}} \mathbf{A}_{\mathbf{M}} \mathbf{A}_{\mathbf{M}} \mathbf{C l}$. $\mathrm{CuCl}(0.752 \mathrm{~g}, 7.60 \mathrm{mmol})$, HMTETA (2.07 mL, $\left.7.60 \mathrm{mmol}\right)$, p-methylstyrene $(20.0 \mathrm{~mL}, 152 \mathrm{mmol})$, and $\mathrm{Cl} \mathbf{A}_{\mathbf{M}} \mathbf{A}_{\mathbf{M}} \mathrm{Cl}(53.0 \mathrm{~mL}, 316 \mathrm{mmol})$ were placed in a $200 \mathrm{~mL}$ round-bottomed flask under dry nitrogen at room temperature $\left(\left[\mathrm{Cl} \mathbf{A}_{\mathbf{M}} \mathbf{A}_{\mathbf{M}} \mathrm{Cl}\right]_{0} /[p \text {-methylstyrene }]_{0} /[\mathrm{CuCl}]_{0} /[\text { HMTETA }]_{0}=4160 / 2000 / 100 / 100 \mathrm{mM}\right.$, total volume: $76.0 \mathrm{~mL}$ ). The flask was placed in an oil bath at $80{ }^{\circ} \mathrm{C}$ under vigorous stirring. The conversion of $p$-methylstyrene was determined by measuring the vinyl group of the residual $p$-methylstyrene by ${ }^{1} \mathrm{H}$ NMR. After $2 \mathrm{~h}$, the conversion of $p$-methylstyrene reached $91 \%$ to form mainly $\mathrm{ClS}_{\mathbf{M}} \mathbf{A}_{\mathbf{M}} \mathbf{A}_{\mathbf{M}} \mathrm{Cl}$. The solution was diluted with $\mathrm{Et}_{2} \mathrm{O}$ and washed three times with aqueous $\mathrm{HCl}$ and then three times with water. The organic layer was evaporated to remove the solvents and was purified by a silica-gel column eluted with $n$-hexane/Et $\mathrm{t}_{2} \mathrm{O}(4 / 1)$. The solvents were evaporated to yield a pale yellow liquid (175 g) containing $\mathrm{ClS}_{\mathbf{M}} \mathbf{A}_{\mathbf{M}} \mathbf{A}_{\mathbf{M}} \mathrm{Cl}$ and unreacted $\mathrm{ClA}_{\mathbf{M}} \mathbf{A}_{\mathbf{M}} \mathrm{Cl}$.

The liquid was then put into a $1 \mathrm{~L}$ round-bottomed flask, into which $\mathrm{CH}_{2} \mathrm{Cl}_{2}(86.5 \mathrm{~mL})$ and allyltrimethylsilane $(45.0 \mathrm{~mL}, 284 \mathrm{mmol})$ were added at room temperature. $\mathrm{TiCl}_{4}(10.4 \mathrm{~mL}$, 94.6 mmol) was added dropwise to the solution cooled at $-78 \quad{ }^{\circ} \mathrm{C}$ 
$\left(\left[\mathrm{ClS}_{\mathbf{M}} \mathbf{A}_{\mathbf{M}} \mathbf{A}_{\mathbf{M}} \mathrm{Cl}\right]_{0} /[\text { allyltrimethylsilane }]_{0} /\left[\mathrm{TiCl}_{4}\right]_{0}=0.51 / 1.5 / 0.50 \mathrm{M}\right.$, total volume: $190 \mathrm{~mL}$; The concentration of $\mathrm{Cl} \mathbf{S}_{\mathbf{M}} \mathbf{A}_{\mathbf{M}} \mathbf{A}_{\mathbf{M}} \mathrm{Cl}$ is the theoretical value based on $100 \%$ yield of $\mathrm{ClS}_{\mathbf{M}} \mathbf{A}_{\mathbf{M}} \mathbf{A}_{\mathbf{M}} \mathrm{Cl}$.). After the mixture was stirred for $2 \mathrm{~h}$ at $-78{ }^{\circ} \mathrm{C}$ and then for $2 \mathrm{~h}$ at $0{ }^{\circ} \mathrm{C}$, ammonia methanol $(75$ $\mathrm{mL}$ ) was added slowly over $30 \mathrm{~min}$ to quench the reaction. The solution was diluted with $\mathrm{Et}_{2} \mathrm{O}$ $(300 \mathrm{~mL})$ and washed with aqueous $\mathrm{Na}_{4}$ EDTA once, aqueous $\mathrm{NaOH}$ twice, and water three times. The organic layer was evaporated to remove the solvents and passed through a silica-gel column with $n$-hexane/Et ${ }_{2} \mathrm{O}(8 / 2)$. After evaporation of the solvents, $\mathrm{VS}_{\mathbf{M}} \mathbf{A}_{\mathbf{M}} \mathbf{A}_{\mathbf{M}} \mathrm{Cl}$ was distilled under reduced pressure $\left(45 \mathrm{~Pa}\right.$, bp. $\left.145^{\circ} \mathrm{C}\right)$ to give a colorless liquid $(19.2 \mathrm{~g}, 54.5 \mathrm{mmol}$, yield $=35.8 \%$ based on $p$-methylstyrene). ${ }^{1} \mathrm{H}$ NMR $\left(\mathrm{CDCl}_{3}, 25^{\circ} \mathrm{C}\right): \delta 1.61-2.70(\mathrm{~m}, 11 \mathrm{H}), 3.50-3.81(\mathrm{~m}$, $\mathrm{CH}-\mathrm{O}, 6 \mathrm{H}), 4.15-4.27(\mathrm{~m}, \mathrm{CH}-\mathrm{Cl}), 4.89-5.03\left(\mathrm{~m}, \mathrm{CH}_{2}=\mathrm{CH}\right), 5.55-5.69(\mathrm{~m}, \mathrm{CH}=\mathrm{CH}), 6.88-7.22$ $(\mathrm{m}, 4 \mathrm{H})$ (Figure S2).

Synthesis of $\mathbf{V S S}_{\mathbf{M}} \mathbf{A}_{\mathbf{M}} \mathbf{C l}$. $\mathrm{RuCl}_{2}\left(\mathrm{PPh}_{3}\right)_{3}(2.17 \mathrm{~g}, 2.26 \mathrm{mmol})$, toluene $(12.0 \mathrm{~mL})$ as an internal standard for gas chromatography, $p$-methylstyrene $(59.7 \mathrm{~mL}, 453 \mathrm{mmol})$, and methyl dichloroacetate $\left(\mathrm{ClA}_{\mathbf{M}} \mathrm{Cl}\right)(155 \mathrm{~mL}, 1.50 \mathrm{~mol})$ were placed in a $300 \mathrm{~mL}$ round-bottomed flask under dry nitrogen at room temperature $\left(\left[\mathrm{ClA} \mathbf{A}_{\mathbf{M}} \mathrm{Cl}\right]_{0} /[p \text {-methylstyrene }]_{0} /\left[\mathrm{RuCl}_{2}\left(\mathrm{PPh}_{3}\right)_{3}\right]_{0}=\right.$ 6610/2000/10 mM, total volume: $227 \mathrm{~mL}$ ). The flask was placed in an oil bath kept at $80{ }^{\circ} \mathrm{C}$ under vigorous stirring. The conversion of $p$-methylstyrene was determined from the concentration of the residual $p$-methylstyrene measured by gas chromatography with toluene as an internal standard. After $40 \mathrm{~h}$, the conversion of $p$-methylstyrene reached $88 \%$ to form $\mathrm{ClS}_{\mathbf{M}} \mathbf{A}_{\mathbf{M}} \mathrm{Cl}$ in $86 \%$ yield. After the precipitation of the ruthenium complex into $n$-hexane, the solution was evaporated to remove the solvents. The product $\left(\mathrm{Cl} \mathbf{S}_{\mathbf{M}} \mathbf{A}_{\mathbf{M}} \mathrm{Cl}\right)$ was distilled under reduced pressure $\left(2 \mathrm{mmHg}\right.$, bp. $\left.102{ }^{\circ} \mathrm{C}\right)$ to give a colorless liquid $(82.5 \mathrm{~g}, 316 \mathrm{mmol}$, yield $=70 \%$ based on $p$-methylstyrene, $d=1.26) . \quad{ }^{1} \mathrm{H}$ NMR $\left(\mathrm{CDCl}_{3}, 25{ }^{\circ} \mathrm{C}\right): \delta 2.30-2.39\left(\mathrm{~s}, \mathrm{CH}_{3}-\mathrm{Ph}\right), 2.39$ $2.54\left(\mathrm{~m}, \mathrm{CH}_{2}-\mathrm{CH}\right), 3.68-3.92\left(\mathrm{~m}, \mathrm{CH}_{3}-\mathrm{O}\right), 4.02-4.68$ (m, $\left.\mathrm{CH}-\mathrm{CO}\right), 4.88-5.22$ (m, $\left.\mathrm{CH}-\mathrm{Ph}\right)$, 6.96-7.56 (m, 4H).

$\mathrm{CH}_{2} \mathrm{Cl}_{2}(165 \mathrm{~mL})$, methylcyclohexane $(21.2 \mathrm{~mL})$, chlorobenzene $(4.6 \mathrm{~mL})$ as an internal standard for gas chromatography, styrene (16.5 mL, $144 \mathrm{mmol})$, and $\mathrm{Cl} \mathbf{S}_{\mathbf{M}} \mathbf{A}_{\mathbf{M}} \mathrm{Cl}$ (27.0 $\mathrm{mL}, 130$ $\mathrm{mmol}$ ) were placed in a $500 \mathrm{~mL}$ round-bottomed flask under dry nitrogen at room temperature. After the solution was cooled to $-40^{\circ} \mathrm{C}$, a mixture of $n \mathrm{Bu}_{4} \mathrm{NCl}(12.0 \mathrm{~mL}$ of $1.30 \mathrm{M}$ solution in $\left.\mathrm{CH}_{2} \mathrm{Cl}_{2}, 15.6 \mathrm{mmol}\right), \mathrm{SnCl}_{4}\left(13.0 \mathrm{~mL}\right.$ of $1.0 \mathrm{M}$ solution in $\left.\mathrm{CH}_{2} \mathrm{Cl}_{2}, 13.0 \mathrm{mmol}\right)$, and $\mathrm{CH}_{2} \mathrm{Cl}_{2}(1.0$ $\mathrm{mL})$ was slowly added $\left([\text { styrene }]_{0} /\left[\mathrm{ClS}_{\mathbf{M}} \mathbf{A}_{\mathbf{M}} \mathrm{Cl}\right]_{0} /\left[\mathrm{SnCl}_{4}\right]_{0} /\left[n \mathrm{Bu}_{4} \mathrm{NCl}\right]_{0}=554 / 500 / 50 / 60 \mathrm{mM}\right.$, total 
volume: $260 \mathrm{~mL}$ ). The conversion of styrene was determined from the concentration of the residual styrene measured by gas chromatography with chlorobenzene as an internal standard. After $24 \mathrm{~h}$, the conversion of styrene reached $99 \%$ to result in a mixture of $\mathrm{ClSS}_{\mathbf{M}} \mathbf{A}_{\mathbf{M}} \mathrm{Cl}$, styrene oligomers, and the remaining $\mathrm{ClS}_{\mathbf{M}} \mathbf{A}_{\mathbf{M}} \mathrm{Cl}$.

After the addition of allyltrimethylsilane solution $(41.3 \mathrm{~mL}, 260 \mathrm{mmol}), \mathrm{TiCl}_{4}(14.3 \mathrm{~mL}, 130$ mmol) was added dropwise to the solution. The solution was stirred for $2 \mathrm{~h}$ at $-40{ }^{\circ} \mathrm{C}$ and for 2 $\mathrm{h}$ at $0{ }^{\circ} \mathrm{C}$. The reaction was quenched with ammonia methanol $(20 \mathrm{~mL})$. The solution was washed with aqueous $1 \mathrm{M} \mathrm{HCl}$ twice, aqueous $0.25 \mathrm{M} \mathrm{NaOH}$ once, and water twice. The organic layer was evaporated to remove the solvents and was passed through a silica-gel column with $n$-hexane/EtOAc $(9 / 1)$ to give the crude product after evaporation of the solvents. The product $\left(\mathrm{VSS}_{\mathbf{M}} \mathbf{A}_{\mathbf{M}} \mathrm{Cl}\right)$ was distilled under reduced pressure $\left(34 \mathrm{~Pa}, \mathrm{bp} .147^{\circ} \mathrm{C}\right)$ to give a colorless liquid $\left(15.2 \mathrm{~g}, 41.0 \mathrm{mmol}\right.$, yield $=32 \%$ based on $\left.\mathrm{ClS}_{\mathbf{M}} \mathbf{A}_{\mathbf{M}} \mathbf{C l}, d=1.07\right) .{ }^{1} \mathrm{H} \mathrm{NMR}\left(\mathrm{CDCl}_{3}\right.$, $\left.25{ }^{\circ} \mathrm{C}\right): \delta 1.77-2.90(\mathrm{~m}, 11 \mathrm{H}), 3.51-3.75\left(\mathrm{~m}, \mathrm{CH}_{3}-\mathrm{O}, 3 \mathrm{H}\right), 3.75-4.12(\mathrm{~m}, \mathrm{CH}-\mathrm{Cl}), 4.79-5.08(\mathrm{~m}$, $\left.\mathrm{CH}_{2}=\mathrm{CH}\right), 5.44-5.74\left(\mathrm{~m}, \mathrm{CH}=\mathrm{CH}_{2}\right), 6.70-7.42(\mathrm{~m}, 9 \mathrm{H})$ (Figure 1A).

Synthesis of $\mathbf{V S S}_{\mathbf{M}} \mathbf{A}_{\mathbf{E}} \mathbf{C l}$. $\mathrm{RuCl}_{2}\left(\mathrm{PPh}_{3}\right)_{3}(2.19 \mathrm{~g}, 2.28 \mathrm{mmol}), n$-octane $(7.5 \mathrm{~mL})$ as an internal standard for gas chromatography, $p$-methylstyrene $(60.3 \mathrm{~mL}, 458 \mathrm{mmol})$, and ethyl dichloroacetate $\left(\mathrm{Cl} \mathbf{A}_{\mathbf{E}} \mathrm{Cl}\right)(161 \mathrm{~mL}, 1.31 \mathrm{~mol})$ were placed in a $300 \mathrm{~mL}$ round-bottomed flask under dry nitrogen at room temperature $\left(\left[\mathrm{Cl} \mathbf{A}_{\mathbf{E}} \mathrm{Cl}\right]_{0} /[p \text {-methylstyrene }]_{0} /\left[\mathrm{RuCl}_{2}\left(\mathrm{PPh}_{3}\right)_{3}\right]_{0}=\right.$ 5750/2010/10 mM, total volume: $228 \mathrm{~mL}$ ). The flask was placed in an oil bath kept at $80{ }^{\circ} \mathrm{C}$ under vigorous stirring. The conversion of $p$-methylstyrene was determined from the concentration of the residual $p$-methylstyrene measured by gas chromatography with $n$-octane as an internal standard. After $94 \mathrm{~h}$, the conversion of $p$-methylstyrene reached $96 \%$ to form mainly $\mathrm{ClS}_{\mathbf{M}} \mathbf{A}_{\mathbf{E}} \mathrm{Cl}$. After the precipitation of the ruthenium complex into $n$-hexane, the solution was evaporated to remove the solvents and was passed through a silica-gel column with $n$-hexane/EtOAc (4/1). The product $\left(\mathrm{ClS}_{\mathbf{M}} \mathbf{A}_{\mathbf{E}} \mathrm{Cl}\right)$ was distilled under reduced pressure (37 $\mathrm{Pa}$, bp. $\left.118{ }^{\circ} \mathrm{C}\right)$ to give a colorless liquid $(48.1 \mathrm{~g}, 175 \mathrm{mmol}$, yield $=38 \%$ based on $p$-methylstyrene, $d=1.14) . \quad{ }^{1} \mathrm{H}$ NMR $\left(\mathrm{CDCl}_{3}, 25{ }^{\circ} \mathrm{C}\right): \delta 1.23-1.46\left(\mathrm{~m}, \mathrm{CH}_{3}-\mathrm{CH}_{2}\right), 2.31-2.39\left(\mathrm{~s}, \mathrm{CH}_{3}-\mathrm{Ph}\right), 2.39-$ 2.82 (m, $\left.\mathrm{CH}_{2}-\mathrm{CH}\right), 4.17-4.32$ (m, $\left.\mathrm{CH}_{3}-\mathrm{O}, 3 \mathrm{H}\right), 4.01-4.72$ (m, $\left.\mathrm{CH}-\mathrm{CO}\right), 5.00-5.22$ (m, $\mathrm{CH}-\mathrm{Ph}$ ), $7.02-7.44(\mathrm{~m}, 4 \mathrm{H})$.

$\mathrm{CH}_{2} \mathrm{Cl}_{2}(131 \mathrm{~mL})$, methylcyclohexane $(16.6 \mathrm{~mL})$, chlorobenzene $(4.4 \mathrm{~mL})$ as an internal standard for gas chromatography, styrene $(13.6 \mathrm{~mL}, 118 \mathrm{mmol})$, and $\mathrm{ClS}_{\mathbf{M}} \mathbf{A}_{\mathbf{E}} \mathrm{Cl}(26.0 \mathrm{~mL}, 108$ 
mmol) were placed in a $300 \mathrm{~mL}$ round-bottomed flask under dry nitrogen at room temperature. After the solution was cooled to $-40{ }^{\circ} \mathrm{C}$, a mixture of $n \mathrm{Bu} 4 \mathrm{NCl}(11.1 \mathrm{~mL}$ of $1.16 \mathrm{M}$ solution in $\left.\mathrm{CH}_{2} \mathrm{Cl}_{2}, 12.9 \mathrm{mmol}\right), \mathrm{SnCl}_{4}\left(10.8 \mathrm{~mL}\right.$ of $1.0 \mathrm{M}$ solution in $\left.\mathrm{CH}_{2} \mathrm{Cl}_{2}, 10.8 \mathrm{mmol}\right)$, and $\mathrm{CH}_{2} \mathrm{Cl}_{2}(1.1$ $\mathrm{mL}$ ) was slowly added ([styrene $]_{0} /\left[\mathrm{Cl} \mathbf{S}_{\mathbf{M}} \mathbf{A}_{\mathbf{E}} \mathrm{Cl}\right]_{0} /\left[\mathrm{SnCl}_{4}\right]_{0} /\left[n \mathrm{Bu}_{4} \mathrm{NCl}\right]_{0}=549 / 502 / 50 / 60 \mathrm{mM}$, total volume: $215 \mathrm{~mL}$ ). The conversion of styrene was determined from the concentration of the residual styrene measured by gas chromatography with chlorobenzene as an internal standard. After $95 \mathrm{~h}$, the conversion of styrene reached $90 \%$ to result in a mixture of $\mathrm{ClSS}_{\mathbf{M}} \mathbf{A}_{\mathbf{E}} \mathrm{Cl}$, styrene oligomers, and the remaining $\mathrm{ClS}_{\mathbf{M}} \mathbf{A}_{\mathbf{E}} \mathrm{Cl}$.

After the addition of allyltrimethylsilane (34.1 mL, $215 \mathrm{mmol}), \mathrm{TiCl}_{4}(11.8 \mathrm{~mL}, 108 \mathrm{mmol})$ was added dropwise to the solution. The solution was stirred for $20 \mathrm{~h}$ at $-40{ }^{\circ} \mathrm{C}$ and for $2 \mathrm{~h}$ at $0{ }^{\circ} \mathrm{C}$. The reaction was quenched with ammonia ethanol $(25 \mathrm{~mL})$. The solution was washed with aqueous $1 \mathrm{M} \mathrm{HCl}$ twice, aqueous $0.25 \mathrm{M} \mathrm{NaOH}$ once, and water twice. The organic layer was evaporated to remove the solvents and was passed through a silica-gel column with $n$-hexane/EtOAc (9/1) to give the crude product after evaporation of the solvents. The product $\left(\mathrm{VSS}_{\mathbf{M}} \mathbf{A}_{\mathbf{E}} \mathrm{Cl}\right)$ was distilled under reduced pressure $\left(13 \mathrm{~Pa}\right.$, bp. $\left.197^{\circ} \mathrm{C}\right)$ to give a colorless liquid $\left(17.1 \mathrm{~g}, 44.4 \mathrm{mmol}\right.$, yield $=41 \%$ based on $\left.\mathrm{ClS}_{\mathbf{M}} \mathbf{A}_{\mathbf{E}} \mathrm{Cl}, d=1.05\right) . \quad{ }^{1} \mathrm{H} \mathrm{NMR}\left(\mathrm{CDCl}_{3}, 25{ }^{\circ} \mathrm{C}\right): \delta$ 0.99-1.34 (m, $\left.\mathrm{CH}_{3}-\mathrm{CH}_{2}\right), 1.76-2.91(\mathrm{~m}, 11 \mathrm{H}), 3.69-3.98$ (m, $\left.\mathrm{CH}-\mathrm{Cl}\right), 3.98-4.28\left(\mathrm{~m}, \mathrm{CH}_{2}-\mathrm{O}\right)$, 4.78-5.01 (m, $\left.\mathrm{CH}_{2}=\mathrm{CH}\right), 5.41-5.73\left(\mathrm{~m}, \mathrm{CH}=\mathrm{CH}_{2}\right), 6.70-7.40(\mathrm{~m}, 9 \mathrm{H})$ (Figure 1B).

Synthesis of VSS $_{\mathbf{M}} \mathbf{N C l}$. $\mathrm{CuCl}(0.197 \mathrm{~g}, 1.99 \mathrm{mmol})$, bpy $(0.944 \mathrm{~g}, 6.04 \mathrm{mmol})$, p-methylstyrene $(39.4 \mathrm{~mL}, 300 \mathrm{mmol})$, and $\mathrm{ClNCl}(48.2 \mathrm{~mL}, 600 \mathrm{mmol})$ were placed in a 200 $\mathrm{mL}$ round-bottomed flask under dry nitrogen at room temperature $\left([\mathrm{ClNCl}]_{0} /[p \text {-methylstyrene }]_{0} /[\mathrm{CuCl}]_{0} /[\mathrm{bpy}]_{0}=6000 / 3000 / 20 / 60 \mathrm{mM}\right.$, total volume: $\left.100 \mathrm{~mL}\right)$. The flask was placed in an oil bath at $80{ }^{\circ} \mathrm{C}$ under vigorous stirring. The conversion of $p$-methylstyrene was determined by measuring the vinyl group of the residual $p$-methylstyrene by ${ }^{1} \mathrm{H}$ NMR. After $19 \mathrm{~h}$, the conversion of $p$-methylstyrene reached $75 \%$ to form $\mathrm{Cl} \mathbf{S}_{\mathbf{M}} \mathrm{NCl}$ in $67 \%$ yield. After the removal of volatiles by evaporation followed by filtration, the product was purified by a silica-gel column eluted with $n$-hexane/EtOAc (4/1). The solvents were evaporated to yield a mixture of $\mathrm{ClS}_{\mathbf{M}} \mathrm{NCl}$ and the remaining $p$-methylstyrene. The product $\left(\mathrm{ClS} \mathbf{S}_{\mathbf{M}} \mathbf{N C l}\right)$ was distilled under reduced pressure $\left(65 \mathrm{~Pa}\right.$, bp. $\left.98^{\circ} \mathrm{C}\right)$ to give a colorless liquid (35.0 $\mathrm{g}, 153 \mathrm{mmol}$, yield $=51 \%$ based on $p$-methylstyrene, $d=1.18) .{ }^{1} \mathrm{H} \mathrm{NMR}\left(\mathrm{CDCl}_{3}, 25{ }^{\circ} \mathrm{C}\right): \delta$ 2.30-2.48 (s, $\left.\mathrm{CH}_{3}-\mathrm{Ph}\right), 2.54-3.02\left(\mathrm{~m}, \mathrm{CH}_{2}-\mathrm{CH}\right), 4.17-4.32,4.42-5.22(\mathrm{~m}, 2 \mathrm{H}), 7.08-7.62$ (m, 
$4 \mathrm{H})$.

$\mathrm{CH}_{2} \mathrm{Cl}_{2}(124 \mathrm{~mL})$, chlorobenzene $(5.8 \mathrm{~mL})$ as an internal standard for gas chromatography, styrene $(19.0 \mathrm{~mL}, 165 \mathrm{mmol})$, and $\mathrm{ClS}_{\mathbf{M}} \mathbf{N C l}(29.0 \mathrm{~mL}, 150 \mathrm{mmol})$ were placed in a $500 \mathrm{~mL}$ round-bottomed under dry nitrogen at room temperature. After cooling the solution at $0{ }^{\circ} \mathrm{C}$, a mixture of $n \mathrm{Bu} 4 \mathrm{NCl}\left(2.68 \mathrm{~mL}\right.$ of $1.12 \mathrm{M}$ solution in $\left.\mathrm{CH}_{2} \mathrm{Cl}_{2}, 3 \mathrm{mmol}\right), \mathrm{ZnCl}_{2}(60 \mathrm{~mL}$ of $1.0 \mathrm{M}$ solution in $\left.\mathrm{Et}_{2} \mathrm{O}, 60 \mathrm{mmol}\right)$, and $\mathrm{CH}_{2} \mathrm{Cl}_{2}(60 \mathrm{~mL})$ was slowly added at $0{ }^{\circ} \mathrm{C}$ ([styrene $]_{0} /\left[\mathrm{ClS} \mathbf{S}_{\mathbf{M}} \mathbf{N C l}\right]_{0} /\left[\mathrm{ZnCl}_{2}\right]_{0} /\left[\mathrm{BBu}_{4} \mathrm{NCl}\right]_{0}=550 / 500 / 200 / 10 \mathrm{mM}$, total volume: $\left.300 \mathrm{~mL}\right)$. The conversion of styrene was determined from the concentration of the residual styrene measured by gas chromatography with chlorobenzene as an internal standard. After $121 \mathrm{~h}$, the conversion of styrene reached $93 \%$ to result in a mixture of $\mathrm{ClSS}_{\mathbf{M}} \mathbf{N C l}(34 \%)$, styrene oligomers (44\%), and the remaining $\mathrm{ClS}_{\mathbf{M}} \mathrm{NCl}(22 \%)$ based on the peak area ratios of their SEC curves monitored by a UV detector at $256 \mathrm{~nm}$.

After the addition of allyltrimethylsilane $(47.6 \mathrm{~mL}, 300 \mathrm{mmol})$, the solution was cooled to $40{ }^{\circ} \mathrm{C}$. $\mathrm{TiCl}_{4}(16.5 \mathrm{~mL}, 150 \mathrm{mmol})$ was added dropwise to the solution. The solution was warmed to $0{ }^{\circ} \mathrm{C}$. The reaction was continued for $166 \mathrm{~h}$ at $0{ }^{\circ} \mathrm{C}$ and quenched with ammonia methanol $(30 \mathrm{~mL})$. The solution was diluted with $\mathrm{Et}_{2} \mathrm{O}(200 \mathrm{~mL})$ and was washed twice with aqueous $\mathrm{NaOH}$ and twice with water. The organic layer was evaporated to remove the solvents and was passed through a silica-gel column with $n$-hexane/EtOAc (4/1) to give the crude product $(5.65 \mathrm{~g})$ after evaporation of the solvents. The product $\left(\mathrm{VSS}_{\mathbf{M}} \mathbf{N C l}\right)$ was further purified by a silica-gel column with $n$-hexane/EtOAc (19/1) to give a pale pink liquid (1.80 g, $5.33 \mathrm{mmol}$, yield $=3.6 \%$ based on $\left.\mathrm{ClS}_{\mathbf{M}} \mathrm{NCl}\right)$ after evaporation of the solvents. ${ }^{1} \mathrm{H} \mathrm{NMR}\left(\mathrm{CDCl}_{3}, 25{ }^{\circ} \mathrm{C}\right): \delta$ 1.80-2.99 (m, 11H), 3.76-4.02 (m, $\mathrm{CH}-\mathrm{Cl}), 4.84-5.08\left(\mathrm{~m}, \mathrm{CH}_{2}=\mathrm{CH}\right), 5.43-5.71\left(\mathrm{~m}, \mathrm{CH}=\mathrm{CH}_{2}\right)$, 6.70-7.54 (m, 9H) (Figure 1C). ${ }^{13} \mathrm{C} \mathrm{NMR}\left(\mathrm{CDCl}_{3}, 25{ }^{\circ} \mathrm{C}\right): \delta 21.18,21.22\left(\mathrm{CH}_{3}-\right), 38.84,39.13$, $40.27,40.55,40.58,40.64,40.77,40.90,40.94,41.04,41.68,41.88,42.18,41.68,41.88,42.18$, $42.36,42.44,42.75,42.88,42.96,43.03,43.29,43.81,44.40\left(-\mathrm{CH}_{2-}\right.$ and $\left.-\mathrm{CH}-\right), 116.32,116.52$ $\left(\mathrm{CH}_{2}=\mathrm{CH}\right), 116.72,116.82,117.48,117.60(\mathrm{CN}-\mathrm{CH}), 126.45,126.52,126.66,127.24,127.48$, $127.56,127.65,127.68,127.79,127.86,127.91,128.55,128.62,129.82,129.88,129.96(C \mathrm{H}$ (Phenyl)), 136.36, 136.41, 137.13, 137.58, 137.94, 138.44, $185.7\left(\mathrm{CH}=\mathrm{CH}_{2}\right.$ and $C$ (Phenyl)), 143.81, 144.00, 144.41 (C (Phenyl)) (Figure S3).

Synthesis of $\mathbf{V S S}_{\mathbf{M}} \mathbf{V}_{\mathbf{D C}} \mathbf{C l}$. $\mathrm{RuCl}_{2}\left(\mathrm{PPh}_{3}\right)_{3}(2.20 \mathrm{~g}, 2.29 \mathrm{mmol}), n$-octane $(4.2 \mathrm{~mL})$ as an internal standard for gas chromatography, $p$-methylstyrene $(60.5 \mathrm{~mL}, 459 \mathrm{mmol})$, and $\mathrm{CCl}_{4}(165$ 
$\mathrm{mL}, 1.71 \mathrm{~mol}$ ) were placed in a $300 \mathrm{~mL}$ round-bottomed flask under dry nitrogen at room temperature $\left(\left[\mathrm{CCl}_{4}\right]_{0} /[p \text {-methylstyrene }]_{0} /\left[\mathrm{RuCl}_{2}\left(\mathrm{PPh}_{3}\right)_{3}\right]_{0}=7430 / 2000 / 10 \mathrm{mM}\right.$, total volume: 230 $\mathrm{mL}$ ). The flask was placed in an oil bath kept at $60{ }^{\circ} \mathrm{C}$ under vigorous stirring. The conversion of $p$-methylstyrene was determined from the concentration of the residual measured $p$-methylstyrene by gas chromatography with $n$-octane as an internal standard. After $25 \mathrm{~h}$, the conversion of $p$-methylstyrene reached $90 \%$ to form $\mathrm{ClS}_{\mathbf{M}} \mathbf{V}_{\mathbf{D C}} \mathrm{Cl}$ in $82 \%$ yield. After the precipitation of the ruthenium complex into $n$-hexane, the solution was evaporated to remove the solvents and was passed through a silica-gel column with $n$-hexane/EtOAc (9/1). The product $\left(\mathrm{ClS}_{\mathbf{M}} \mathbf{V}_{\mathbf{D C}} \mathrm{Cl}\right)$ was distilled under reduced pressure $\left(26 \mathrm{~Pa}, \mathrm{bp} .101{ }^{\circ} \mathrm{C}\right)$ to give a colorless liquid (97.9 g, $360 \mathrm{mmol}$, yield $=78 \%$ based on $p$-methylstyrene, $d=1.31) . \quad{ }^{1} \mathrm{H} \mathrm{NMR}\left(\mathrm{CDCl}_{3}, 25{ }^{\circ} \mathrm{C}\right)$ :

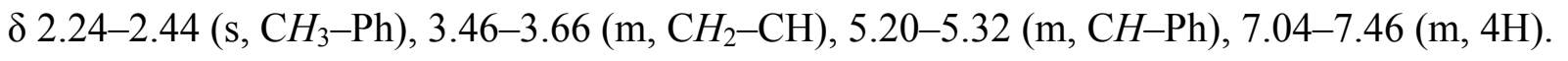

$\mathrm{CH}_{2} \mathrm{Cl}_{2}(164 \mathrm{~mL})$, methylcyclohexane $(23.1 \mathrm{~mL})$, chlorobenzene $(4.2 \mathrm{~mL})$ as an internal standard for gas chromatography, styrene $(17.0 \mathrm{~mL}, 148 \mathrm{mmol})$, and $\mathrm{ClS}_{\mathbf{M}} \mathbf{V}_{\mathbf{D C}} \mathrm{Cl}$ (27.8 $\mathrm{mL}, 134$ mmol) were placed in a $300 \mathrm{~mL}$ round-bottomed flask under dry nitrogen at room temperature. After the solution was cooled to $-40{ }^{\circ} \mathrm{C}$, a mixture of $n \mathrm{Bu}_{4} \mathrm{NCl}(15.2 \mathrm{~mL}$ of $1.07 \mathrm{M}$ solution in $\left.\mathrm{CH}_{2} \mathrm{Cl}_{2}, 16.3 \mathrm{mmol}\right), \mathrm{SnCl}_{4}\left(13.4 \mathrm{~mL}\right.$ of $1.0 \mathrm{M}$ solution in $\left.\mathrm{CH}_{2} \mathrm{Cl}_{2}, 13.4 \mathrm{mmol}\right), \mathrm{EtOAc}(0.66 \mathrm{~mL}$, $6.7 \mathrm{mmol})$, and $\mathrm{CH}_{2} \mathrm{Cl}_{2} \quad(2.93 \quad \mathrm{~mL})$ was slowly added ([styrene $]_{0} /\left[\mathrm{ClS}_{\mathbf{M}} \mathbf{V}_{\mathbf{D C}} \mathrm{Cl}_{0} /\left[\mathrm{SnCl}_{4}\right]_{0} /\left[\mathrm{nBu}_{4} \mathrm{NCl}\right]_{0} /[\mathrm{EtOAc}]_{0}=552 / 500 / 50 / 61 / 25 \mathrm{mM}\right.$, total volume: $268 \mathrm{~mL}$ ). The conversion of styrene was determined from the concentration of the residual styrene measured by gas chromatography with chlorobenzene as an internal standard. The conversion of styrene reached only $5.2 \%$ after $72 \mathrm{~h}$. Then, $5.0 \mathrm{~mL}$ of $1.0 \mathrm{M} \mathrm{SnCl}_{4}$ solution in $\mathrm{CH}_{2} \mathrm{Cl}_{2}(5.0 \mathrm{mmol})$ was added. After $3 \mathrm{~h}$, the conversion reached $87 \%$ to result in a mixture of $\mathrm{ClSS}_{\mathbf{M}} \mathbf{V}_{\mathbf{D C}} \mathrm{Cl}$, styrene oligomers, and the remaining $\mathrm{ClS}_{\mathbf{M}} \mathbf{V}_{\mathbf{D C}} \mathrm{Cl}$.

After the addition of allyltrimethylsilane (42.6 mL, $268 \mathrm{mmol}^{2}, \mathrm{TiCl}_{4}(14.7 \mathrm{~mL}, 134 \mathrm{mmol})$ was added dropwise to the solution. The solution was stirred for $2 \mathrm{~h}$ at $-40{ }^{\circ} \mathrm{C}$ and for $2 \mathrm{~h}$ at $0{ }^{\circ} \mathrm{C}$. The reaction was quenched with ammonia methanol $(30 \mathrm{~mL})$. The solution was washed with aqueous $1 \mathrm{M} \mathrm{HCl}$ twice, aqueous $0.25 \mathrm{M} \mathrm{NaOH}$ once, and water twice. The organic layer was evaporated to remove the solvents and was passed through a silica-gel column with $n$-hexane/EtOAc $(9 / 1)$ to give the crude product after evaporation of the solvents. The product $\left(\mathrm{VSS}_{\mathbf{M}} \mathbf{V}_{\mathbf{D C}} \mathrm{Cl}\right)$ was distilled under reduced pressure $\left(5 \mathrm{~Pa}, \mathrm{bp} .160^{\circ} \mathrm{C}\right)$ to give a colorless liquid (21.1 g, $63.6 \mathrm{mmol}$, yield $=47.5 \%$ based on $\left.\mathrm{ClS}_{\mathbf{M}} \mathbf{V}_{\mathbf{D C}} \mathrm{Cl}, d=1.15\right) . \quad{ }^{1} \mathrm{H} \mathrm{NMR}\left(\mathrm{CDCl}_{3}, 25{ }^{\circ} \mathrm{C}\right): \delta$ $1.90-2.78(\mathrm{~m}, 8 \mathrm{H}), 2.79-3.45(\mathrm{~m}, 3 \mathrm{H}), 4.77-5.30\left(\mathrm{~m}, \mathrm{CH}_{2}=\mathrm{CH}\right), 5.50-5.98\left(\mathrm{~m}, \mathrm{CH}=\mathrm{CH}_{2}\right), 6.80-$ 
$7.68(\mathrm{~m}, 9 \mathrm{H})$ (Figure 1D).

Synthesis of VSA $\mathbf{M M}_{\mathbf{D M}} \mathbf{C l}$. $\mathrm{Me}_{2} \mathrm{NH}(345 \mathrm{~mL}$ of $2.0 \mathrm{M}$ solution in methanol, $690 \mathrm{mmol})$ was slowly added into $\mathrm{VSA}_{\mathbf{M}} \mathbf{A}_{\mathbf{M}} \mathrm{Cl}(19.5 \mathrm{~mL}, d=1.20,69.1 \mathrm{mmol})$ in a $500 \mathrm{~mL}$ round-bottomed flask at $20{ }^{\circ} \mathrm{C}\left(\left[\mathrm{VSA}_{\mathbf{M}} \mathbf{A}_{\mathbf{M}} \mathrm{Cl}\right]_{0} /\left[\mathrm{Me}_{2} \mathrm{NH}\right]_{0}=189 / 1890 \mathrm{mM}\right.$, total volume: $\left.365 \mathrm{~mL}\right)$. After $40 \mathrm{~h}$, the terminal methyl ester unit was converted into a dimethylamide unit in $90 \%$. The solution was diluted with $\mathrm{Et}_{2} \mathrm{O}$ and washed with water three times. After the evaporation of the solvents, the product (VSA $\left.\mathbf{A M}_{\mathbf{M}} \mathbf{M}_{\mathbf{M}} \mathrm{Cl}\right)$ was purified by a silica-gel column with $n$-hexane $/ \mathrm{Et}_{2} \mathrm{O}(3 / 71)$ to give a colorless liquid (12.3 g, $38.5 \mathrm{mmol}$, yield $=56 \%$ based on $\left.\mathbf{V S A}_{\mathbf{M}} \mathbf{A}_{\mathbf{M}} \mathrm{Cl}, d=1.10\right)$ after evaporation of the solvents. ${ }^{1} \mathrm{H}$ NMR $\left(\mathrm{CDCl}_{3}, 25^{\circ} \mathrm{C}\right): \delta 1.69-2.82(\mathrm{~m}, 8 \mathrm{H}), 2.86-3.13(\mathrm{~m}$, $\left.\mathrm{CH}_{3}-\mathrm{N}\right), 3.40-3.71\left(\mathrm{~m}, \mathrm{CH}_{3}-\mathrm{O}\right), 4.31-4.48\left(\mathrm{~m}, \mathrm{CH}_{2}-\mathrm{Cl}\right), 4.84-5.02\left(\mathrm{~m}, \mathrm{CH}_{2}=\mathrm{CH}\right), 5.50-5.69$ (m, $\left.\mathrm{CH}=\mathrm{CH}_{2}\right), 7.05-7.34(\mathrm{~m}, 5 \mathrm{H})($ Figure $2 \mathrm{~A}) .{ }^{13} \mathrm{C} \mathrm{NMR}\left(\mathrm{CDCl}_{3}, 25{ }^{\circ} \mathrm{C}\right): \delta 35.64,36.21,36.71$, $37.23,37.28,37.40,38.20,38.29,38.81,39.64,39.77,40.78,41.48,41.65,41.68,43.34,43.42$ $\left(-\mathrm{CH}_{2-},-\mathrm{CH}-\right.$, and $\left.\mathrm{CH}_{3}-\mathrm{N}\right), 51.05,51.72,51.76,51.80,52.51,52.87\left(\mathrm{CH}_{3}-\mathrm{O}\right.$, or $\left.\mathrm{CH}-\mathrm{Cl}\right), 116.42$, $116.49,116.58\left(\mathrm{CH}_{2}=\mathrm{CH}\right), 126.49,126.53,126.56,127.77,127.90,128.47,128.52(\mathrm{CH}$ (Phenyl)), 136.34, 136.37, $137.42\left(\mathrm{CH}=\mathrm{CH}_{2}\right), 143.46,143.72,143.80$ ( $C$ (Phenyl)), 167.74, $168.18,168.44(C \mathrm{O}-\mathrm{N}), 175.50,175.54,175.92$ (CO-O) (Figure S4).

Synthesis of $\mathbf{V S A}_{\mathbf{M}} \mathbf{M}_{\mathbf{N P}} \mathbf{C l}$. $n \mathrm{PrNH}_{2}(48.5 \mathrm{~mL}, 591 \mathrm{mmol})$ was slowly added into $\mathrm{VSA}_{\mathbf{M}} \mathbf{A}_{\mathbf{M}} \mathrm{Cl}(16.7 \mathrm{~mL}, d=1.20,59.2 \mathrm{mmol})$ in a $200 \mathrm{~mL}$ round-bottomed at $20{ }^{\circ} \mathrm{C}$ $\left(\left[\mathrm{VSA}_{\mathbf{M}} \mathbf{A}_{\mathbf{M}} \mathrm{Cl}\right]_{0} /\left[n \mathrm{PrNH}_{2}\right]_{0}=908 / 906 \mathrm{mM}\right.$, total volume: $\left.65.2 \mathrm{~mL}\right)$. After $8 \mathrm{~h}$, the terminal methyl ester unit was converted into an $n$-propylamide unit nearly completely (99\%). The solution was diluted with $\mathrm{Et}_{2} \mathrm{O}$ and was washed with water three times. After the evaporation of the solvents, the product $\left(\mathrm{VSA}_{\mathbf{M}} \mathbf{M}_{\mathbf{N P}} \mathrm{Cl}\right.$ ) was purified by a silica-gel column with $\mathrm{CHCl}_{3} / \mathrm{MeOH}$ (70/1) to give a colorless liquid $\left(9.48 \mathrm{~g}, 25.9 \mathrm{mmol}\right.$, yield $=44 \%$ based on $\left.\mathrm{VSA}_{\mathbf{M}} \mathbf{A}_{\mathbf{M}} \mathrm{Cl}, d=1.00\right)$ after evaporation of the solvents. ${ }^{1} \mathrm{H}$ NMR $\left(\mathrm{CDCl}_{3}, 25^{\circ} \mathrm{C}\right): \delta 0.76-1.02\left(\mathrm{~m}, \mathrm{CH}_{3}-\mathrm{CH}_{2}\right), 1.36-$ $1.60\left(\mathrm{~m}, \mathrm{CH}_{2}-\mathrm{CH}_{3}\right), 1.62-2.80(\mathrm{~m}, 8 \mathrm{H}), 3.09-3.30\left(\mathrm{~m}, \mathrm{CH}_{2}-\mathrm{NH}\right), 3.44-3.74\left(\mathrm{~m}, \mathrm{CH}_{3}-\mathrm{O}\right), 4.10-$ $4.32(\mathrm{~m}, \mathrm{CH}-\mathrm{Cl}), 4.83-5.02\left(\mathrm{~m}, \mathrm{CH}_{2}=\mathrm{CH}\right), 5.51-5.73\left(\mathrm{~m}, \mathrm{CH}=\mathrm{CH}_{2}\right), 6.29-6.52\left(\mathrm{~m}, \mathrm{NH}-\mathrm{CH}_{2}\right)$, 7.03-7.42 (m, 5H) (Figure 2B).

Synthesis of $\mathbf{V S A}_{\mathbf{M}} \mathbf{M}_{\mathbf{I P}} \mathbf{C l} . \quad i \mathrm{PrNH}_{2}(134 \mathrm{~mL}, 1.56 \mathrm{~mol})$ was slowly added into $\mathrm{VSA}_{\mathbf{M}} \mathbf{A}_{\mathbf{M}} \mathrm{Cl}$ (22.1 $\mathrm{mL}, \quad d=1.20,78.2 \mathrm{mmol})$ in a $200 \mathrm{~mL}$ round-bottomed flask at $20{ }^{\circ} \mathrm{C}$ 
$\left(\left[\mathrm{VSA}_{\mathbf{M}} \mathbf{A}_{\mathbf{M}} \mathrm{Cl}\right]_{0} /\left[i \mathrm{PrNH}_{2}\right]_{0}=501 / 1000 \mathrm{mM}\right.$, total volume: $\left.156 \mathrm{~mL}\right)$. After $69 \mathrm{~h}$, the terminal methyl ester unit was converted into an isopropylamide unit nearly completely (99\%). The solution was diluted with $\mathrm{Et}_{2} \mathrm{O}$ and was washed with water three times. After the evaporation of the solvents, the product ( $\mathrm{VSA}_{\mathbf{M}} \mathbf{M}_{\mathbf{I P}} \mathrm{Cl}$ ) was purified by a silica-gel column with $\mathrm{CHCl}_{3} / \mathrm{MeOH}$ $(75 / 1)$ to give a white solid $\left(17.0 \mathrm{~g}, 46.5 \mathrm{mmol}\right.$, yield $=59 \%$ based on $\left.\mathrm{VS}_{\mathbf{M}} \mathbf{A}_{\mathbf{M}} \mathbf{A}_{\mathbf{M}} \mathrm{Cl}\right)$ after evaporation of the solvents. ${ }^{1} \mathrm{H}$ NMR $\left(\mathrm{CDCl}_{3}, 25{ }^{\circ} \mathrm{C}\right): \delta 1.05-1.25\left(\mathrm{~m}, \mathrm{CH}_{3}-\mathrm{CH}\right), 1.64-2.75(\mathrm{~m}$, 8H), 3.47-3.72 (m, $\left.\mathrm{CH}_{3}-\mathrm{O}\right), 3.91-4.09$ (m, $\left.\mathrm{CH}-\mathrm{NH}\right), 4.11-4.28$ (m, $\left.\mathrm{CH}-\mathrm{Cl}\right), 4.89-5.05$ (m, $\left.\mathrm{CH}_{2}=\mathrm{CH}\right), 5.52-5.73\left(\mathrm{~m}, \mathrm{CH}=\mathrm{CH}_{2}\right), 6.09-6.31(\mathrm{~m}, \mathrm{NH}-\mathrm{CH}), 7.05-7.42(\mathrm{~m}, 5 \mathrm{H})$ (Figure 2C).

Synthesis of VSAMM $\mathbf{M}_{\mathbf{H E}} \mathbf{C l}$. Ethanolamine $(4.28 \mathrm{~mL}, 70.9 \mathrm{mmol})$ was slowly added into $\mathrm{VSA}_{\mathbf{M}} \mathbf{A}_{\mathbf{M}} \mathrm{Cl}(13.3 \mathrm{~mL}, d=1.20,47.1 \mathrm{mmol})$ in a $50 \mathrm{~mL}$ round-bottomed flask at $20{ }^{\circ} \mathrm{C}$ $\left(\left[\mathrm{VSA}_{\mathbf{M}} \mathbf{A}_{\mathbf{M}} \mathrm{Cl}\right]_{0} /[\text { ethanolamine }]_{0}=2680 / 4030 \mathrm{mM}\right.$, total volume: $\left.17.6 \mathrm{~mL}\right)$. After $1.5 \mathrm{~h}$, the terminal methyl ester unit was converted into a 2-hydoxylethylamide unit nearly completely (99\%). The solution was diluted with $\mathrm{Et}_{2} \mathrm{O}$ and was washed with water three times. After the evaporation of the solvents, the product ( $\left.\mathbf{V S A}_{\mathbf{M}} \mathbf{M}_{\mathbf{H E}} \mathrm{Cl}\right)$ was purified by a silica-gel column with $\mathrm{CHCl}_{3} / \mathrm{MeOH}(17 / 1)$ to give a colorless liquid $(11.4 \mathrm{~g}, 31.0 \mathrm{mmol}$, yield $=66 \%$ based on $\left.\operatorname{VSA}_{\mathbf{M}} \mathbf{A}_{\mathbf{M}} \mathrm{Cl}, d=1.12\right)$ after evaporation of the solvents. ${ }^{1} \mathrm{H}$ NMR $\left(\mathrm{CDCl}_{3}, 25{ }^{\circ} \mathrm{C}\right): \delta 1.62-2.72$ (m, 9H), 3.22-3.77 (m, 7H), 4.17-4.33 (m, $\mathrm{CH}-\mathrm{Cl}), 4.85-5.04\left(\mathrm{~m}, \mathrm{CH}_{2}=\mathrm{CH}\right), 5.48-5.73(\mathrm{~m}$, $\left.\mathrm{CH}=\mathrm{CH}_{2}\right), 6.66-6.92\left(\mathrm{~m}, \mathrm{NH}-\mathrm{CH}_{2}\right), 7.05-7.42(\mathrm{~m}, 5 \mathrm{H})$ (Figure 2D).

Synthesis of VSV. THF (507 mL) and $\alpha, \alpha$-dichlorotoluene (ClSCl) $(93 \mathrm{~mL}, 724 \mathrm{mmol})$ were placed in a $2 \mathrm{~L}$ round-bottomed flask under dry nitrogen at room temperature. After the solution was cooled to $-78{ }^{\circ} \mathrm{C}$, allylmagnesium chloride $(900 \mathrm{~mL}$ of $2.0 \mathrm{M}$ THF solution, 1.8 mol) was added dropwise to the solution over $3 \mathrm{~h}\left([\mathrm{ClSCl}]_{0} /[\text { allylmagnesium chloride }]_{0}=\right.$ 483/1200 mM, total volume: $1500 \mathrm{~mL}$ ). The solution was stirred at $-78^{\circ} \mathrm{C}$ for $26 \mathrm{~h}$. After the solution was gradually warmed to $20^{\circ} \mathrm{C}$ over $90 \mathrm{~h}$, the reaction was continued for $145 \mathrm{~h}$ at $20{ }^{\circ} \mathrm{C}$ and for $6 \mathrm{~h}$ at $40^{\circ} \mathrm{C}$. The reaction was quenched with ammonia methanol $(160 \mathrm{~mL})$. After the solution was evaporated to remove the solvents, the solution was diluted with $\mathrm{Et}_{2} \mathrm{O}(500 \mathrm{~mL})$ and washed with aqueous $\mathrm{HCl}$ once, aqueous $\mathrm{NaHCO}_{3}$ once, and aqueous $\mathrm{NaCl}$ twice. The organic layer was evaporated to remove the solvents. The product (VSV) was distilled under reduced pressure $\left(6 \mathrm{mmHg}\right.$, bp. $\left.76^{\circ} \mathrm{C}\right)$ to give a colorless liquid $(64.5 \mathrm{~g}, 375 \mathrm{mmol}$, yield $=52 \%$ based on $\mathrm{ClSCl}, d=0.922) . \quad{ }^{1} \mathrm{H}$ NMR $\left(\mathrm{CDCl}_{3}, 25^{\circ} \mathrm{C}\right): \delta 2.20-2.82(\mathrm{~m}, 5 \mathrm{H}), 4.78-5.08\left(\mathrm{~m}, \mathrm{CH}_{2}=\mathrm{CH}\right)$, 
5.54-5.74 (m, $\left.\mathrm{CH}=\mathrm{CH}_{2}\right), 7.00-7.38(\mathrm{~m}, 5 \mathrm{H})$ (Figure 3A).

Synthesis of VSSV. $\quad \mathrm{RuCl}_{2}\left(\mathrm{PPh}_{3}\right)_{3}(1.92 \mathrm{~g}, 2.00 \mathrm{mmol})$, toluene $(8.0 \mathrm{~mL})$ as an internal standard for gas chromatography, styrene $(45.8 \mathrm{~mL}, 400 \mathrm{mmol})$, and $\alpha, \alpha$-dichlorotoluene (ClSCl) $(146 \mathrm{~mL}, 1.13 \mathrm{~mol})$ were placed in a $500 \mathrm{~mL}$ round-bottomed flask under dry nitrogen at room temperature $\left([\mathrm{ClSCl}]_{0} /[\text { styrene }]_{0} /\left[\mathrm{RuCl}_{2}\left(\mathrm{PPh}_{3}\right)_{3}\right]_{0}=5650 / 2000 / 10 \mathrm{mM}\right.$, total volume: $\left.200 \mathrm{~mL}\right)$. The flask was placed in an oil bath at $100{ }^{\circ} \mathrm{C}$ under vigorous stirring. The conversion of styrene was determined from the concentration of the residual styrene measured by gas chromatography with toluene as an internal standard. After $24 \mathrm{~h}$, the conversion of styrene reached $95 \%$ to form mainly ClSSCl. After the precipitation of the ruthenium complex into $n$-hexane, the solvent was evaporated to give the crude product. The obtained product was passed through a silica-gel column with $n$-hexane/EtOAC (9/1). After evaporation of the solvents, the product (ClSSCl) was distilled under reduced pressure $\left(30 \mathrm{~Pa}, \mathrm{bp} .107^{\circ} \mathrm{C}\right)$ to give a colorless liquid $(\mathrm{ClSSCl})(14.5$ g, 54.9 mmol, yield $=13.7 \%$ based on styrene, $d=1.12) . \quad{ }^{1} \mathrm{H} \mathrm{NMR}\left(\mathrm{CDCl}_{3}, 25{ }^{\circ} \mathrm{C}\right): \delta 2.60-3.04$ (m, $\left.\mathrm{CH}_{2}-\mathrm{CH}\right), 4.70-5.32(\mathrm{~m}, \mathrm{CH}-\mathrm{Cl}), 7.26-7.52(\mathrm{~m}, 10 \mathrm{H})$.

THF (228 mL) and CISSCl $(36.5 \mathrm{~mL}, 154 \mathrm{mmol})$ were placed in a $1 \mathrm{~L}$ round-bottomed flask under dry nitrogen at room temperature. After cooling the solution to $-50{ }^{\circ} \mathrm{C}$, allylmagnesium chloride (176 mL of $2.0 \mathrm{M}$ THF solution, $352 \mathrm{mmol}$ ) was added dropwise over $20 \mathrm{~min}$ $\left([\mathrm{ClSSCl}]_{0} /[\text { allylmagnesium chloride }]_{0}=550 / 800 \mathrm{mM}\right.$, total volume: $\left.441 \mathrm{~mL}\right)$. The solution was stirred at $-50{ }^{\circ} \mathrm{C}$ for $14.5 \mathrm{~h},-30{ }^{\circ} \mathrm{C}$ for $3 \mathrm{~h}, 0{ }^{\circ} \mathrm{C}$ for $3.5 \mathrm{~h}, 20{ }^{\circ} \mathrm{C}$ for $44 \mathrm{~h}$, and $40{ }^{\circ} \mathrm{C}$ for 152 $\mathrm{h}$ (total $217 \mathrm{~h})$. The reaction was quenched with ammonia methanol $(50 \mathrm{~mL})$. After evaporation of the solvents, the solution was diluted with toluene $(150 \mathrm{~mL})$ and washed with water four times. The organic layer was evaporated to remove the solvents. The product (VSSV) was distilled under reduced pressure $\left(50 \mathrm{~Pa}, \mathrm{bp} .100^{\circ} \mathrm{C}\right)$ to give a colorless liquid $(16.3 \mathrm{~g}$, 59.0 mmol, yield $=38.3 \%$ based on ClSSCl, $d=0.949) . \quad{ }^{1} \mathrm{H}$ NMR $\left(\mathrm{CDCl}_{3}, 25{ }^{\circ} \mathrm{C}\right): \delta 1.73-2.71$ (m, 8H), 4.79-4.98 (m, $\left.\mathrm{CH}_{2}=\mathrm{CH}\right), 5.40-5.66\left(\mathrm{~m}, \mathrm{CH}=\mathrm{CH}_{2}\right), 6.94-7.54(\mathrm{~m}, 10 \mathrm{H})$ (Figure 3B).

Synthesis of VSA $\mathbf{M}$ SV. $\quad \mathrm{RuCl}_{2}\left(\mathrm{PPh}_{3}\right)_{3}(2.50 \mathrm{~g}, 8.00 \mathrm{mmol})$, toluene $(12.0 \mathrm{~mL})$ as an internal standard for gas chromatography, styrene $(60.0 \mathrm{~mL}, 522 \mathrm{mmol})$, and methyl dichloroacetate $\left(\mathrm{Cl} \mathbf{A}_{\mathbf{M}} \mathrm{Cl}\right)(189 \mathrm{~mL}, 1.83 \mathrm{~mol})$ were placed in a $500 \mathrm{~mL}$ round-bottomed flask under dry nitrogen at room temperature $\left(\left[\mathrm{Cl} \mathbf{A}_{\mathbf{M}} \mathrm{Cl}\right]_{0} /[\text { styrene }]_{0} /\left[\mathrm{RuCl}_{2}\left(\mathrm{PPh}_{3}\right)_{3}\right]_{0}=7010 / 2000 / 10 \mathrm{mM}\right.$, total volume: $261 \mathrm{~mL}$ ). The flask was placed in an oil bath kept at $60{ }^{\circ} \mathrm{C}$ under vigorous stirring. The 
conversion of styrene was determined from the concentration of the residual styrene measured by gas chromatography with toluene as an internal standard. After $164 \mathrm{~h}$, the conversion of styrene reached $79 \%$ to form $\mathrm{ClSA} \mathbf{A}_{\mathbf{M}} \mathrm{Cl}$ in $67 \%$ yield. After the precipitation of the ruthenium complex into $n$-hexane, the solvent was evaporated to give the crude product. The product $\left(\mathrm{ClSA} \mathbf{A}_{\mathbf{M}} \mathrm{Cl}\right)$ was distilled under reduced pressure $\left(5 \mathrm{mmHg}, \mathrm{bp} .82^{\circ} \mathrm{C}\right)$ to give a colorless liquid $(47.9 \mathrm{~g}, 194$ mmol, yield $=37 \%$ based on styrene, $d=1.22) . \quad{ }^{1} \mathrm{H} \mathrm{NMR}\left(\mathrm{CDCl}_{3}, 25{ }^{\circ} \mathrm{C}\right): \delta 2.38-2.85(\mathrm{~m}$, $\left.\mathrm{CH}_{2}-\mathrm{CH}\right), 3.74-3.88$ (m, $\left.\mathrm{CH}_{3}-\mathrm{O}, 3 \mathrm{H}\right), 4.06-4.76$ (m, $\left.\mathrm{CH}-\mathrm{CO}\right), 4.98-5.24$ (m, $\left.\mathrm{CH}-\mathrm{Ph}\right), 7.28-$ $7.52(\mathrm{~m}, 5 \mathrm{H})$.

$\mathrm{CuCl}$ (0.446 g, $4.51 \mathrm{mmol})$, HMTETA (1.23 mL, $4.51 \mathrm{mmol})$, styrene (10.4 mL, $90.4 \mathrm{mmol})$, and $\mathrm{ClSA}_{\mathbf{M}} \mathrm{Cl}(30.0 \mathrm{~mL}, 148 \mathrm{mmol})$ were placed in a $100 \mathrm{~mL}$ round-bottomed flask under dry nitrogen at room temperature $\left(\left[\mathrm{ClSA} \mathbf{M}_{\mathbf{M}} \mathrm{Cl}\right]_{0} /[\text { styrene }]_{0} /[\mathrm{CuCl}]_{0} /[\text { HMTETA }]_{0}=3560 / 2170 / 11 / 11\right.$ $\mathrm{mM}$, total volume: $41.6 \mathrm{~mL}$ ). The flask was placed in an oil bath at $80{ }^{\circ} \mathrm{C}$ under vigorous stirring. The conversion of styrene was determined by measuring the vinyl group of the residual styrene by ${ }^{1} \mathrm{H}$ NMR. After $4 \mathrm{~h}$, the conversion of styrene reached $87 \%$ to form mainly $\mathrm{ClSA}_{\mathbf{M}} \mathrm{SCl}$. The solution was diluted with $\mathrm{Et}_{2} \mathrm{O}$ and washed with water three times. The organic layer was evaporated to remove the solvents and purified by a silica-gel column eluted with $n$-hexane/EtOAc (1/1) to remove the catalysts. The solvents were evaporated to yield an orange liquid (30 g) containing the product ( $\left.\mathrm{ClSA} \mathbf{A M}_{\mathbf{M}} \mathbf{S C l}, 39 \%\right)$, another adduct $\left(\mathrm{ClSS} \mathbf{A}_{\mathbf{M}} \mathrm{Cl}, 5 \%\right)$, and unreacted $\mathrm{ClSA} \mathbf{A}_{\mathbf{M}} \mathrm{Cl}(56 \%)$.

The liquid was then put into a $200 \mathrm{~mL}$ round-bottomed flask, into which $\mathrm{CH}_{2} \mathrm{Cl}_{2}(82.8 \mathrm{~mL})$ and allyltrimethylsilane $(54.4 \mathrm{~mL}, 345 \mathrm{mmol})$ were added at room temperature. $\mathrm{TiCl}_{4}(3.77 \mathrm{~mL}$, $34.3 \mathrm{mmol}$ ) was added dropwise to the solution cooled at $-78 \quad{ }^{\circ} \mathrm{C}$ $\left(\left[\mathrm{ClSA} \mathbf{M S C l}_{0} /[\text { allyltrimethylsilane }]_{0} /\left[\mathrm{TiCl}_{4}\right]_{0}=0.53 / 2.0 / 0.20 \mathrm{M}\right.\right.$, total volume: $171 \mathrm{~mL}$; The concentration of $\mathrm{ClSA}_{\mathbf{M}} \mathbf{S C l}$ is the theoretical value based on $100 \%$ yield of $\mathrm{ClSA}_{\mathbf{M}} \mathbf{S C l}$.). After the mixture was stirred at $-78{ }^{\circ} \mathrm{C}$ for $1 \mathrm{~h}$, at $0{ }^{\circ} \mathrm{C}$ for $69 \mathrm{~h}$, and at $20{ }^{\circ} \mathrm{C}$ for 7 days, ammonia methanol $(20 \mathrm{~mL})$ was added over $30 \mathrm{~min}$ to quench the reaction. The solution was diluted with $\mathrm{Et}_{2} \mathrm{O}(70 \mathrm{~mL})$ and washed with aqueous $\mathrm{NaOH}$ three times and water three times. The organic layer was evaporated to remove the solvents and was passed through a silica-gel column with $n$-hexane/EtOAc (4/1). In addition to $\mathrm{VSA}_{\mathrm{M}} \mathrm{SV}$, the products contained $\mathrm{VSA}_{\mathbf{M}} \mathrm{Cl}$, which was obtained via allylation of the remaining $\mathbf{C l S} \mathbf{A}_{\mathbf{M}} \mathrm{Cl}$.

To remove the $\mathrm{VSA}_{\mathbf{M}} \mathrm{Cl}$ efficiently using column chromatography based on differences in polarity, the acrylate unit adjacent to the $\mathrm{C}-\mathrm{Cl}$ bond in $\mathrm{VSA}_{\mathbf{M}} \mathrm{Cl}$ was selectively amidated by 
ethanolamine (35 g mixture of the crude products in $142 \mathrm{~mL}$ of ethanolamine). The reaction was run at $0{ }^{\circ} \mathrm{C}$ for $58 \mathrm{~h}$ to convert the remaining $\mathrm{VSA}_{\mathbf{M}} \mathrm{Cl}$ into $\mathrm{VSM}_{\mathbf{H E}} \mathrm{Cl}$, in which the methyl ester was converted into 2-hydroxylethylamide without affecting the ester group in VSAMSV. The solution was diluted with $\mathrm{Et}_{2} \mathrm{O}$ and was washed with aqueous $\mathrm{HCl}$ once and water three times. The organic layer was evaporated to remove the solvents. The remaining $\mathrm{VSM}_{\mathbf{H E}} \mathrm{Cl}$ was nearly completely removed by a silica-gel column with $n$-hexane/EtOAc (4/1). After evaporation of the solvents, $\mathrm{VSA}_{\mathrm{M}} \mathrm{SV}$ was distilled under reduced pressure $\left(7 \mathrm{~Pa}, \mathrm{bp} .120^{\circ} \mathrm{C}\right)$ to give a colorless liquid $(12.0 \mathrm{~g}, 33.1 \mathrm{mmol}$, yield $=36.7 \%$ based on styrene, $d=0.940) . \quad{ }^{1} \mathrm{H}$ NMR $\left(\mathrm{CDCl}_{3}, 25{ }^{\circ} \mathrm{C}\right): \delta 1.48-2.72(\mathrm{~m}, 11 \mathrm{H}), 3.20-3.64\left(\mathrm{~m}, \mathrm{CH}_{3}-\mathrm{O}\right), 4.73-5.02\left(\mathrm{~m}, \mathrm{CH}_{2}=\mathrm{CH}\right)$, 5.40-5.68 (m, $\left.\mathrm{CH}=\mathrm{CH}_{2}\right), 6.78-7.38(\mathrm{~m}, 10 \mathrm{H})$ (Figure $\left.3 \mathrm{C}\right) .{ }^{13} \mathrm{C} \mathrm{NMR}\left(\mathrm{CDCl}_{3}, 25{ }^{\circ} \mathrm{C}\right): \delta 38.22$, $38.33,38.86,39.20,41,20,41.24,41.42,41.64,42.02,42.24,43.68,43.89,44.12\left(-\mathrm{CH}_{2}-\right.$ and $-\mathrm{CH}-), 51.33,51.38,51.47\left(\mathrm{CH}_{3}-\mathrm{O}\right), 116.35,116.49\left(\mathrm{CH}_{2}=\mathrm{CH}\right), 126.33,126.41,126.52,127.76$, 127.84, 127.94, 128.43, 128.48, 128.52 ( $\mathrm{CH}$ (Phenyl)), 136.57, 136.61, $136.74\left(\mathrm{CH}=\mathrm{CH}_{2}\right)$, 143.80, 144.11, 144.24, 144.27 (C (Phenyl)), 176.34, 176.58, 176.63 (CO-O) (Figure S5).

Synthesis of CINV $\mathbf{E E V}_{\mathbf{C}}$ NCl. $\mathrm{CuCl}(0.495 \mathrm{~g}, 5.00 \mathrm{mmol}), \mathrm{CuCl}_{2}(0.673 \mathrm{~g}, 5.00 \mathrm{mmol})$, bpy $(12.5 \mathrm{~g}, 80.0 \mathrm{mmol})$, toluene $(1.0 \mathrm{~mL})$ as an internal standard for ${ }^{1} \mathrm{H} \mathrm{NMR}$ analysis, 1,8-nonadiene (VEEV) (16.8 mL, $100 \mathrm{mmol})$, and dichloroacetonitrile $(\mathrm{ClNCl})(68.5 \mathrm{~mL}, 853$ mmol) were placed in a $200 \mathrm{~mL}$ round-bottomed flask under dry nitrogen at room temperature $\left([\mathrm{ClNCl}]_{0} /[\mathrm{VEEV}]_{0} /[\mathrm{CuCl}]_{0} /\left[\mathrm{CuCl}_{2}\right]_{0} /[\mathrm{bpy}]_{0}=8530 / 1000 / 50 / 50 / 800 \mathrm{mM}\right.$, total volume: $\left.100 \mathrm{~mL}\right)$. The flask was placed in an oil bath at $100{ }^{\circ} \mathrm{C}$ under vigorous stirring. The conversion of VEEV was determined by measuring the vinyl group of the residual VEEV by ${ }^{1} \mathrm{H}$ NMR. After $7 \mathrm{~h}$, the conversion of the $\mathrm{C}=\mathrm{C}$ bond in VEEV reached $98 \%$ to form mainly $\mathrm{ClNV} \mathbf{E E E V}_{\mathbf{C}} \mathbf{N C l}$. The solution was diluted with $\mathrm{Et}_{2} \mathrm{O}$ and was washed with aqueous $\mathrm{HCl}$ three times and water three times. After the organic layer was evaporated to remove the solvents, the remaining $\mathrm{ClNCl}$ was removed by a neutral alumina column eluted with $n$-hexane/ $\mathrm{Et}_{2} \mathrm{O}(1 / 1)$. After evaporation of the solvents, the crude product was diluted with $\mathrm{CH}_{2} \mathrm{Cl}_{2}$ and treated with activated carbon to remove the catalysts. The product $\left(\mathrm{ClNV}_{\mathbf{C}} \mathbf{E E V} \mathbf{V}_{\mathbf{C}} \mathbf{N C l}\right)$ was further purified by a silica-gel column with $n$-hexane $/ \mathrm{Et}_{2} \mathrm{O}(4 / 1)$ to give a colorless liquid $(22.4 \mathrm{~g}, 65.1 \mathrm{mmol}$, yield $=65.1 \%$ based on VEEV, $d=1.19)$ after evaporation of the solvents. ${ }^{1} \mathrm{H}$ NMR $\left(\mathrm{CDCl}_{3}, 25{ }^{\circ} \mathrm{C}\right): \delta 1.21-1.72(\mathrm{~m}, 6 \mathrm{H}), 1.72-$ 1.92 (q, $\left.\mathrm{CH}-\mathrm{CH}_{2}-\mathrm{CH}_{2}\right), 3.98-4.20\left(\mathrm{~m}, \mathrm{CH}_{2}-\mathrm{CH}-\mathrm{CH}_{2}\right), 4.72-4.92(\mathrm{~m}, \mathrm{Cl}-\mathrm{CH}-\mathrm{CN})$ (Figure 4C). 
Metal-Catalyzed Step-Growth Radical Polymerization of $\mathbf{V S}_{\mathbf{M}} \mathbf{N N C l}$. Polymerization was carried out by the syringe technique under dry nitrogen in a sealed glass tube. A typical example of the polymerization procedure is given below. A mixture of $\mathrm{CuCl}(28.0 \mathrm{mg}, 0.283$ $\mathrm{mmol})$ and bpy $(0.342 \mathrm{~g}, 2.19 \mathrm{mmol})$ in toluene $(0.23 \mathrm{~mL})$ was stirred for $12 \mathrm{~h}$ at $80{ }^{\circ} \mathrm{C}$ to give a solution of the $\mathrm{CuCl} / \mathrm{bpy}$ complex. After the solution was cooled to room temperature, $\mathrm{VS}_{\mathbf{M}} \mathbf{N N C l}(2.20 \mathrm{~mL}, 8.13 \mathrm{mmol})$ was added $\left(\left[\mathrm{VS}_{\mathbf{M}} \mathbf{N N C l}\right]_{0} /[\mathrm{CuCl}]_{0} /[\mathrm{bpy}]_{0}=2903 / 101 / 782 \mathrm{mM}\right.$, total volume: $2.80 \mathrm{~mL}$ ). The solution was evenly distributed in 6 glass tubes, and the tubes were sealed by flame under a nitrogen atmosphere. The tubes were immersed in a thermostatic oil bath at $100{ }^{\circ} \mathrm{C}$. At predetermined intervals, the polymerization was terminated by cooling the reaction mixtures to $-78{ }^{\circ} \mathrm{C}$. The conversions of the functional groups $(\mathrm{C}=\mathrm{C}$ and $\mathrm{C}-\mathrm{Cl})$ of $\mathrm{VS}_{\mathbf{M}} \mathrm{NNCl}$ were determined from the residual concentrations of $\mathrm{C}=\mathrm{C}$ and $\mathrm{C}-\mathrm{Cl}$ by ${ }^{1} \mathrm{H}$ NMR spectroscopy with toluene as an internal standard. The quenched reaction solutions were diluted with toluene and washed with water three times. The organic layer was evaporated to dryness to give the product polymers $\left(150 \mathrm{~h}\right.$, Conv. $(\mathrm{C}-\mathrm{Cl})=95 \%$, Conv. $(\mathrm{C}=\mathrm{C})=83 \%, M_{\mathrm{n}}=1300, M_{\mathrm{w}}=$ $\left.2100, M_{\mathrm{w}} / M_{\mathrm{n}}=1.64\right)$.

\section{Metal-Catalyzed Step-Growth Radical Polymerization between CINCl and VSAMSV.} Polymerization was carried out by the syringe technique under dry nitrogen in a sealed glass tube. A typical example of the polymerization procedure is given below. A mixture of $\mathrm{CuCl}(49.5 \mathrm{mg}$, $0.500 \mathrm{mmol})$ and bpy $(0.625 \mathrm{~g}, 4.00 \mathrm{mmol})$ in toluene $(0.83 \mathrm{~mL})$ was stirred for $12 \mathrm{~h}$ at $80{ }^{\circ} \mathrm{C}$ to give a solution of the $\mathrm{CuCl} / \mathrm{bpy}$ complex. After the solution was cooled to room temperature, ClNCl (0.60 mL, $7.47 \mathrm{mmol})$ and VSAMSV $(2.89 \mathrm{~mL}, 7.49 \mathrm{mmol})$ were added $\left([\mathrm{ClNCl}]_{0} /\left[\mathrm{VSA}_{\mathbf{M}} \mathbf{S V}\right]_{0} /[\mathrm{CuCl}]_{0} /[\mathrm{bpy}]_{0}=1500 / 1500 / 100 / 800 \mathrm{mM}\right.$, total volume: $\left.5.0 \mathrm{~mL}\right)$. The solution was evenly distributed in 7 glass tubes, and the tubes were sealed by flame under a nitrogen atmosphere. The tubes were immersed in a thermostatic oil bath at $100{ }^{\circ} \mathrm{C}$. At predetermined intervals, the polymerization was terminated by cooling the reaction mixtures to $78{ }^{\circ} \mathrm{C}$. The conversions of the functional groups $(\mathrm{C}=\mathrm{C}$ and $\mathrm{C}-\mathrm{Cl})$ of $\mathrm{VSA}_{\mathbf{M}} \mathbf{S V}$ and $\mathrm{ClNCl}$ were determined from the residual concentrations of $\mathrm{C}=\mathrm{C}$ and $\mathrm{C}-\mathrm{Cl}$ by ${ }^{1} \mathrm{H}$ NMR spectroscopy with toluene as an internal standard. The quenched reaction solutions were diluted with toluene and washed with water three times. The organic layer was evaporated to dryness to give the product polymers $\left(380 \mathrm{~h}\right.$, Conv. $(\mathrm{C}-\mathrm{Cl})=98 \%$, Conv. $(\mathrm{C}=\mathrm{C})=93 \%, M_{\mathrm{n}}=2300, M_{\mathrm{w}}=8400, M_{\mathrm{w}} / M_{\mathrm{n}}=$ $3.65)$. 
Measurements. $\quad{ }^{1} \mathrm{H}$ NMR spectra were recorded in $\mathrm{CDCl}_{3}$ at $25{ }^{\circ} \mathrm{C}$ on a JEOL ESC-400 spectrometer operating at $400 \mathrm{MHz}$. MALDI-TOF-MS spectra were measured on a Shimadzu AXIMA-CFR Plus mass spectrometer (linear mode) with trans-2-[3-(4-tert-buthylphenyl)-2-methyl-2-propenylidene]-malononitrile (DCTB) as the ionizing matrix and sodium trifluoroacetate as the ion source. The number-average molecular weight $\left(M_{\mathrm{n}}\right)$ and molecular weight distribution $\left(M_{\mathrm{w}} / M_{\mathrm{n}}\right)$ of the product polymers were determined by SEC in THF at $40{ }^{\circ} \mathrm{C}$ on two polystyrene gel columns [Tosoh Multipore $\mathrm{H}_{\mathrm{XL}}-\mathrm{M}$ (7.8 mm i.d. $\times 30 \mathrm{~cm}) \times 2$; flow rate $1.0 \mathrm{~mL} / \mathrm{min}$ ] connected to a JASCO PU-2080 precision pump and a JASCO RI-2031 detector. The columns were calibrated against standard polystyrene samples (Varian; $\left.M_{\mathrm{p}}=580-3053000, M_{\mathrm{w}} / M_{\mathrm{n}}=1.02-1.23\right)$. The glass transition temperature $\left(T_{\mathrm{g}}\right)$ of the polymers was recorded on a Q200 differential scanning calorimeter (TA Instruments Inc.). Samples were first heated to $120^{\circ} \mathrm{C}$ at $10{ }^{\circ} \mathrm{C} / \mathrm{min}$, equilibrated at this temperature for $10 \mathrm{~min}$, and cooled to $-50{ }^{\circ} \mathrm{C}$ at $10{ }^{\circ} \mathrm{C} / \mathrm{min}$. After being held at this temperature for $5 \mathrm{~min}$, the samples were then reheated to $120{ }^{\circ} \mathrm{C}$ at $10{ }^{\circ} \mathrm{C} / \mathrm{min}$. All $T_{\mathrm{g}}$ values were obtained from the second scan after removing the thermal history.

\section{References}

1. Satoh, K.; Ozawa, S.; Mizutani, M.; Nagai, K.; Kamigaito, M. Sequence-regulated vinyl copolymers by metal-catalysed step-growth radical polymerization, Nat. Commun. 2010, 1, 6. 
Table S1. Metal-Catalyzed Step-Growth Radical Polymerization of Various ab-Type Monomers with $\mathrm{ABCC}$ and $\mathrm{ABCD}$ Sequences

\begin{tabular}{|c|c|c|c|c|c|c|c|c|c|c|}
\hline entry & monomer & cat/ligand & $\begin{array}{c}{[\mathrm{cat}]_{0} /[\text { ligand }]_{0}} \\
\mathrm{mM}\end{array}$ & solvent & $\begin{array}{l}\text { temp. } \\
\left({ }^{\circ} \mathrm{C}\right)\end{array}$ & $\begin{array}{l}\text { time } \\
\text { (h) }\end{array}$ & $\begin{array}{c}\text { conv. }^{d} \\
\mathrm{C}=\mathrm{C}\end{array}$ & $\begin{array}{l}\text { conv. }^{d} \\
\mathrm{C}-\mathrm{Cl}\end{array}$ & $M_{\mathrm{w}}{ }^{e}$ & $M_{\mathrm{w}} / M_{\mathrm{n}}{ }^{c}$ \\
\hline $1^{a}$ & $\mathrm{VSS}_{\mathbf{M}} \mathbf{A}_{\mathbf{M}} \mathrm{Cl}$ & $\mathrm{RuCp} * \mathrm{Cl}\left(\mathrm{PPh}_{3}\right)_{2}$ & 100 & toluene & 100 & 380 & $38 \%$ & $49 \%$ & 840 & 1.20 \\
\hline $2^{a}$ & $\mathrm{VSS}_{\mathbf{M}} \mathbf{A}_{\mathbf{M}} \mathrm{Cl}$ & $\mathrm{FeC}_{2} / \mathrm{P} n \mathrm{Bu}_{3}$ & $100 / 200$ & toluene & 100 & 360 & $31 \%$ & $41 \%$ & 830 & 1.17 \\
\hline $3^{a}$ & $\mathrm{VSS}_{\mathbf{M}} \mathbf{A}_{\mathbf{M}} \mathrm{Cl}$ & $\mathrm{CuCl} / \mathrm{HMTETA}$ & $100 / 100$ & toluene & 60 & 360 & $17 \%$ & $18 \%$ & 920 & 1.31 \\
\hline $4^{a}$ & $\mathrm{VSS}_{\mathbf{M}} \mathbf{A}_{\mathbf{M}} \mathrm{Cl}$ & $\mathrm{CuCl} / \mathrm{HMTETA}$ & $200 / 800$ & DMF & 60 & 240 & $55 \%$ & $69 \%$ & 2500 & 1.89 \\
\hline $5^{a}$ & $\mathrm{VSS}_{\mathbf{M}} \mathbf{A}_{\mathbf{M}} \mathrm{Cl}$ & $\mathrm{CuCl} / \mathrm{Me}_{6} \mathrm{TREN}$ & $200 / 800$ & $\mathrm{DMF}$ & 60 & 340 & $29 \%$ & $60 \%$ & 1600 & 1.53 \\
\hline $6^{a}$ & $\mathrm{VSS}_{\mathbf{M}} \mathbf{A}_{\mathbf{M}} \mathrm{Cl}$ & $\mathrm{CuCl} / \mathrm{PMDETA}$ & $200 / 800$ & $\mathrm{DMF}$ & 60 & 120 & $60 \%$ & $70 \%$ & 2500 & 1.70 \\
\hline 7 & $\mathrm{VS}_{\mathbf{M}} \mathbf{N N C l}$ & $\mathrm{CuCl} / \mathrm{PMDETA}$ & $200 / 800$ & bulk & 60 & 59 & $65 \%$ & $84 \%$ & 2400 & 1.60 \\
\hline 8 & $\mathrm{VS}_{\mathbf{M}} \mathbf{N N C l}$ & $\mathrm{CuCl} / \mathrm{dNbpy}$ & $200 / 400$ & bulk & 100 & 500 & $77 \%$ & $78 \%$ & 2300 & 1.50 \\
\hline 9 & $\mathrm{VS}_{\mathbf{M}} \mathbf{N N C l}$ & $\mathrm{CuCl} / \mathrm{bpy}$ & $200 / 1600$ & bulk & 100 & 100 & $76 \%$ & $99 \%$ & 3300 & 1.83 \\
\hline 10 & $\mathrm{VS}_{\mathbf{M}} \mathbf{N N C l}$ & $\mathrm{CuCl} / \mathrm{bpy}$ & $100 / 800$ & bulk & 100 & 150 & $83 \%$ & $95 \%$ & 2100 & 1.64 \\
\hline 11 & $\mathrm{VS}_{\mathbf{M}} \mathbf{A}_{\mathbf{M}} \mathbf{A}_{\mathbf{M}} \mathrm{Cl}$ & $\mathrm{CuCl} / \mathrm{bpy}$ & $200 / 1600$ & bulk & 100 & 600 & $30 \%$ & $36 \%$ & 1200 & 1.16 \\
\hline 12 & $\mathrm{VS}_{\mathbf{M}} \mathbf{A}_{\mathbf{M}} \mathbf{A}_{\mathbf{M}} \mathrm{Cl}$ & $\mathrm{CuCl} / \mathrm{PMDETA}$ & $200 / 800$ & bulk & 60 & 500 & $70 \%$ & $74 \%$ & 4700 & 2.36 \\
\hline 13 & $\mathrm{VSS}_{\mathbf{M}} \mathbf{N C l}$ & $\mathrm{CuCl} / \mathrm{bpy}$ & $100 / 800$ & bulk & 100 & 500 & $66 \%$ & $69 \%$ & 3300 & 1.86 \\
\hline 14 & $\mathrm{VSA}_{\mathbf{M}} \mathbf{M}_{\mathbf{D M}} \mathrm{Cl}$ & $\mathrm{CuCl} / \mathrm{PMDETA}$ & $200 / 800$ & bulk & 60 & 450 & $47 \%$ & $60 \%$ & 1000 & 1.64 \\
\hline 15 & $\mathrm{VSA}_{\mathbf{M}} \mathbf{A}_{\mathbf{M}} \mathrm{Cl}$ & $\mathrm{CuCl} / \mathrm{PMDETA}$ & $200 / 800$ & bulk & 60 & 456 & $64 \%$ & $71 \%$ & 3600 & 3.47 \\
\hline 16 & $\mathrm{VSA}_{\mathbf{M}} \mathbf{M}_{\mathbf{N P}} \mathrm{Cl}$ & $\mathrm{CuCl} / \mathrm{PMDETA}$ & $200 / 800$ & bulk & 60 & 456 & $44 \%$ & $64 \%$ & 1500 & 1.35 \\
\hline $17^{b}$ & $\mathrm{VSA}_{\mathbf{M}} \mathbf{M}_{\mathbf{D M}} \mathrm{Cl}$ & $\mathrm{CuCl} / \mathrm{PMDETA}$ & $400 / 400$ & $\mathrm{DMF}$ & 80 & 770 & $29 \%$ & $52 \%$ & 580 & 1.30 \\
\hline $18^{b}$ & $\mathrm{VSA}_{\mathbf{M}} \mathbf{M}_{\mathbf{D M}} \mathrm{Cl}$ & $\mathrm{CuCl} / \mathrm{Me}_{6} \mathrm{TREN}$ & $400 / 400$ & DMF & 80 & 708 & $39 \%$ & $61 \%$ & 750 & 1.42 \\
\hline $19^{b}$ & $\mathrm{VSA}_{\mathbf{M}} \mathbf{M}_{\mathbf{D M}} \mathrm{Cl}$ & $\mathrm{CuCl} / \mathrm{HMTETA}$ & $400 / 400$ & $\mathrm{DMF}$ & 80 & 700 & $40 \%$ & $65 \%$ & 810 & 1.47 \\
\hline $20^{c}$ & $\mathrm{VSA}_{\mathbf{M}} \mathbf{M}_{\mathbf{D M}} \mathrm{Cl}$ & $\mathrm{CuCl} / \mathrm{HMTETA}$ & $400 / 400$ & $\mathrm{DMF}$ & 80 & 310 & $49 \%$ & $83 \%$ & 950 & 1.63 \\
\hline $21^{c}$ & $\mathrm{VSA}_{\mathbf{M}} \mathbf{M}_{\mathbf{N P}} \mathrm{Cl}$ & $\mathrm{CuCl} / \mathrm{HMTETA}$ & $400 / 400$ & $\mathrm{DMF}$ & 80 & 643 & $47 \%$ & $72 \%$ & 1700 & 1.55 \\
\hline $22^{c}$ & $\mathrm{VSA}_{\mathbf{M}} \mathbf{M}_{\mathbf{I P}} \mathrm{Cl}$ & $\mathrm{CuCl} / \mathrm{HMTETA}$ & $400 / 400$ & $\mathrm{DMF}$ & 80 & 290 & $28 \%$ & $\underline{f}$ & 1100 & 1.50 \\
\hline $23^{c}$ & $\mathrm{VSA}_{\mathbf{M}} \mathbf{M}_{\mathbf{H E}} \mathrm{Cl}$ & $\mathrm{CuCl/HMTETA}$ & $400 / 400$ & DMF & 80 & 312 & $47 \%$ & $81 \%$ & 2400 & 1.62 \\
\hline $24^{a}$ & $\mathrm{VSS}_{\mathbf{M}} \mathbf{V}_{\mathbf{D C}} \mathrm{Cl}$ & $\mathrm{CuCl} / \mathrm{PMDETA}$ & $100 / 100$ & toluene & 60 & 270 & $0 \%$ & $\stackrel{f}{-}$ & - & - \\
\hline $25^{a}$ & $\mathrm{VSS}_{\mathbf{M}} \mathbf{V}_{\mathbf{D C}} \mathrm{Cl}$ & CuCl/HMTETA & $100 / 100$ & toluene & 60 & 360 & $3 \%$ & $\underline{f}$ & 800 & 1.14 \\
\hline $26^{a}$ & $\mathrm{VSS}_{\mathbf{M}} \mathbf{V}_{\mathbf{D C}} \mathrm{Cl}$ & $\mathrm{FeCl}_{2} / \mathrm{P} n \mathrm{Bu}_{3}$ & $100 / 200$ & toluene & 60 & 335 & $19 \%$ & $\underline{f}$ & 910 & 1.20 \\
\hline $27^{a}$ & $\mathrm{VSS}_{\mathbf{M}} \mathbf{V}_{\mathbf{D C}} \mathrm{Cl}$ & $\mathrm{FeCl}_{2} / \mathrm{P} n \mathrm{Bu}_{3}$ & $100 / 200$ & toluene & 100 & 100 & $46 \%$ & $f$ & 960 & 1.20 \\
\hline $28^{a}$ & $\mathrm{VSS}_{\mathbf{M}} \mathbf{V}_{\mathbf{D C}} \mathrm{Cl}$ & $\mathrm{RuCp} * \mathrm{Cl}\left(\mathrm{PPh}_{3}\right)_{2}$ & 100 & toluene & 100 & 100 & $70 \%$ & $f$ & 1000 & 1.23 \\
\hline
\end{tabular}

${ }^{a}[\text { monomer }]_{0}=2.0 \mathrm{M} .{ }^{b}[\text { monomer }]_{0}=2.3 \mathrm{M} . \quad{ }^{c}[\text { monomer }]_{0}=1.7 \mathrm{M} .{ }^{d}$ Determined by ${ }^{1} \mathrm{H}$ NMR. ${ }^{e}$ Determined by SEC. ${ }^{e}$ Not measured due to the overlapping of the peaks or due to no appropriate protons for measuring by ${ }^{1} \mathrm{H}$ NMR. 
Table S2. Metal-Catalyzed Step-Growth Radical Polymerization between aa- and bb-Type Monomers $^{a}$

\begin{tabular}{|c|c|c|c|c|c|c|c|c|c|c|}
\hline entry & aa-monomer & bb-monomer & cat/ligand & $\begin{array}{c}{[\text { cat }]_{0} /[\text { ligand }]_{0}} \\
\mathrm{mM}\end{array}$ & $\begin{array}{l}\text { temp. } \\
\left({ }^{\circ} \mathrm{C}\right)\end{array}$ & $\begin{array}{l}\text { time } \\
\text { (h) }\end{array}$ & $\begin{array}{l}\text { conv. }^{e} \\
\mathrm{C}=\mathrm{C}\end{array}$ & $\begin{array}{l}\text { conv. }^{e} \\
\mathrm{C}-\mathrm{Cl}\end{array}$ & $M_{\mathrm{w}}^{f}$ & $M_{\mathrm{w}} / M_{\mathrm{n}}^{f}$ \\
\hline $1^{b}$ & $\mathrm{ClA}_{\mathrm{M}} \mathrm{Cl}$ & VEEV & CuCl/PMDETA & $100 / 400$ & 60 & 145 & $31 \%$ & $46 \%$ & 510 & 1.22 \\
\hline $2^{b}$ & $\mathrm{Cl} \mathbf{A}_{M} \mathbf{A}_{M} \mathrm{Cl}$ & VEEV & $\mathrm{CuCl} / \mathrm{PMDETA}$ & $100 / 400$ & 60 & 480 & $22 \%$ & $47 \%$ & 1100 & 1.41 \\
\hline $3^{b}$ & $\mathrm{ClNCl}$ & VEEV & $\mathrm{CuCl} / \mathrm{bpy}$ & $100 / 800$ & 100 & 360 & $93 \%$ & $99 \%$ & 6000 & 2.69 \\
\hline $4^{b}$ & ClNNCl & VEEV & $\mathrm{CuCl} / \mathrm{bpy}$ & $100 / 800$ & 100 & 670 & $78 \%$ & $93 \%$ & 1400 & 1.75 \\
\hline $5^{c}$ & $\mathrm{ClNCl}$ & VSSV & $\mathrm{CuCl} / \mathrm{bpy}$ & $100 / 800$ & 100 & 460 & $90 \%$ & $95 \%$ & 7400 & 3.88 \\
\hline $6^{c}$ & $\mathrm{ClNCl}$ & $\mathrm{VSA}_{\mathbf{M}} \mathbf{S V}$ & $\mathrm{CuCl} / \mathrm{bpy}$ & $100 / 800$ & 100 & 380 & $93 \%$ & $98 \%$ & 8400 & 3.65 \\
\hline $7^{d}$ & $\operatorname{CINV}_{\mathbf{C}} \mathbf{E E V} \mathbf{V}_{\mathrm{C}} \mathbf{N C l}$ & $\mathrm{VSA}_{\mathbf{M}} \mathbf{S V}$ & $\mathrm{CuCl} / \mathrm{bpy}$ & $100 / 800$ & 100 & 320 & $96 \%$ & $91 \%$ & 9000 & 3.12 \\
\hline
\end{tabular}

${ }_{\text {toluene. }}{ }^{b}[\text { aa-monomer }]_{0}=[\text { bb-monomer }]_{0}=2.0 \mathrm{M} .{ }^{c}[\text { aa-monomer }]_{0}=[\text { bb-monomer }]_{0}=1.5$ M. ${ }^{d}[\text { aa-monomer }]_{0}=$ $[\text { bb-monomer }]_{0}=1.0 \mathrm{M} .{ }^{e}$ Determined by ${ }^{1} \mathrm{H}$ NMR. $\quad{ }^{f}$ Determined by SEC. 


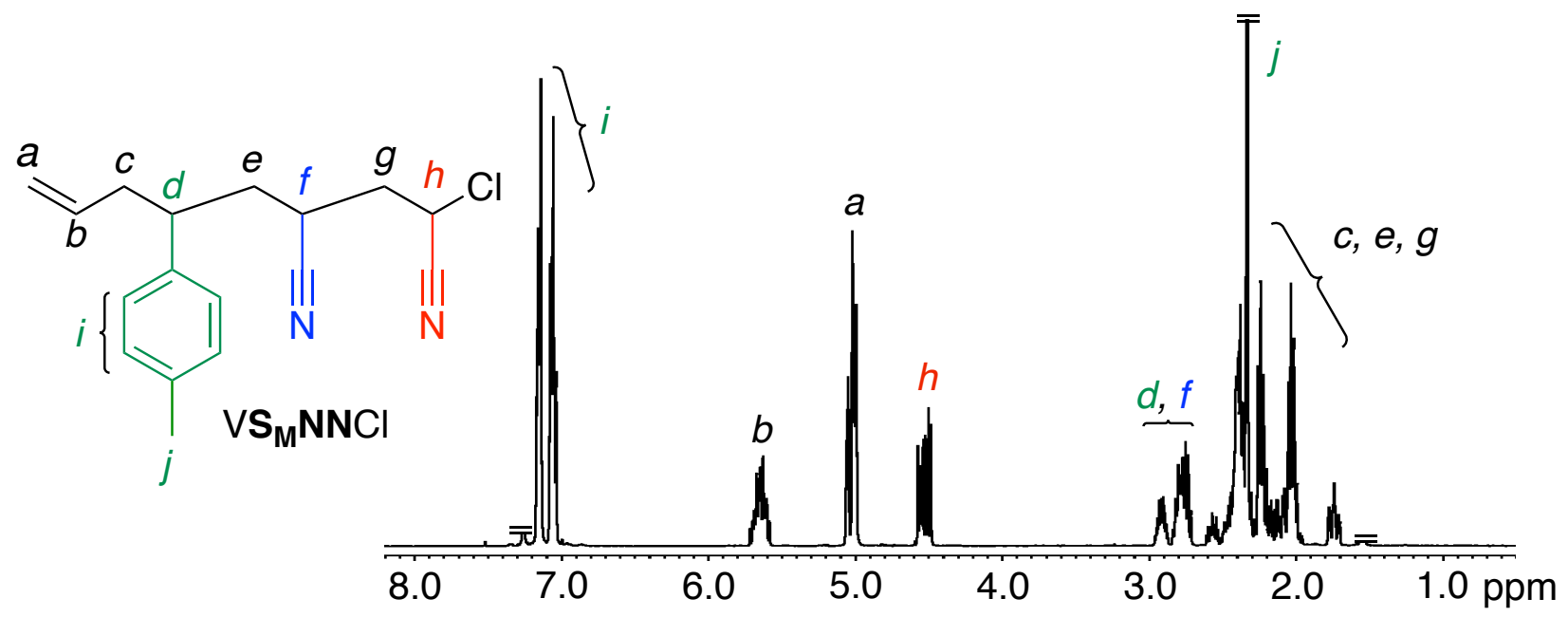

Figure S1. ${ }^{1} \mathrm{H}$ NMR spectrum $\left(\mathrm{CDCl}_{3}, 25^{\circ} \mathrm{C}\right)$ of $\mathrm{ClS}_{\mathbf{M}} \mathbf{N N C l}$.

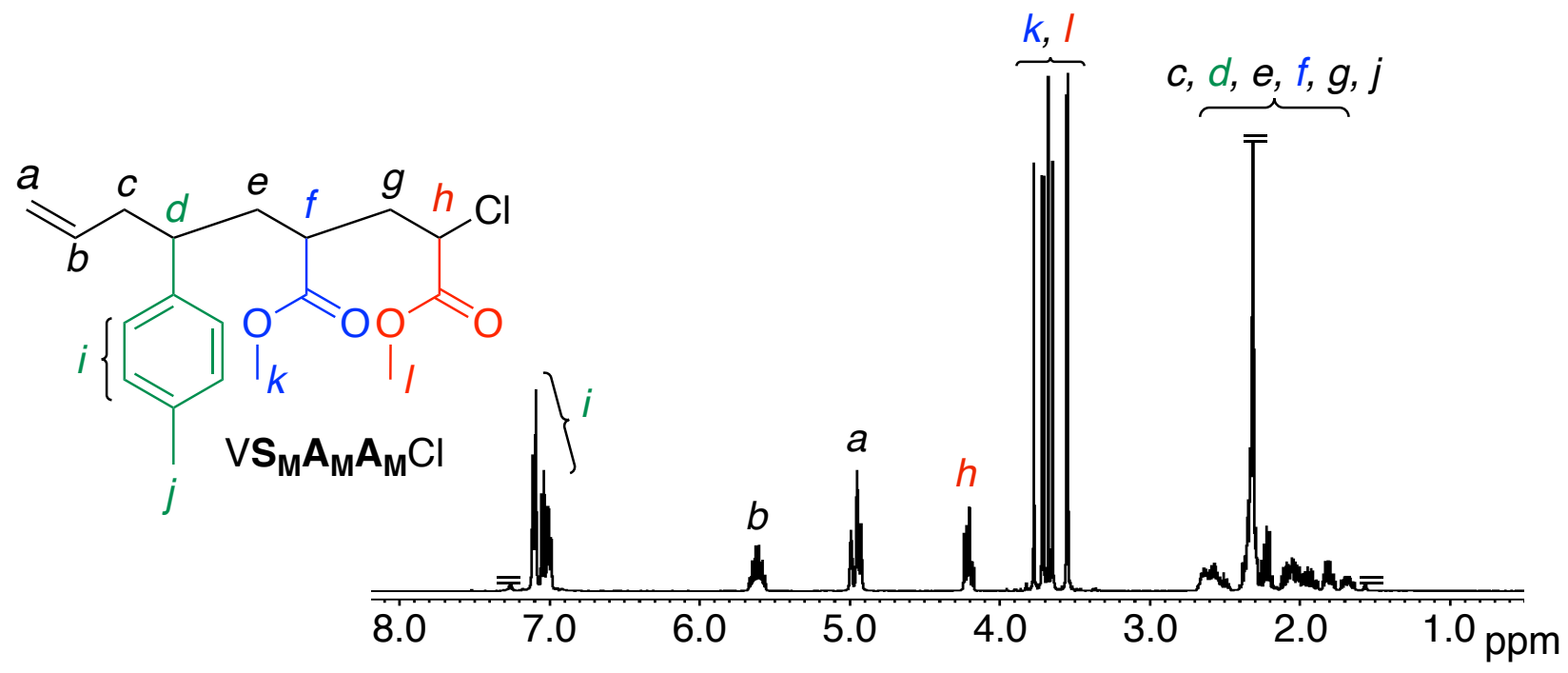

Figure S2. ${ }^{1} \mathrm{H}$ NMR spectrum $\left(\mathrm{CDCl}_{3}, 25^{\circ} \mathrm{C}\right)$ of $\mathrm{VS}_{\mathbf{M}} \mathbf{A}_{\mathbf{M}} \mathbf{A}_{\mathbf{M}} \mathrm{Cl}$. 


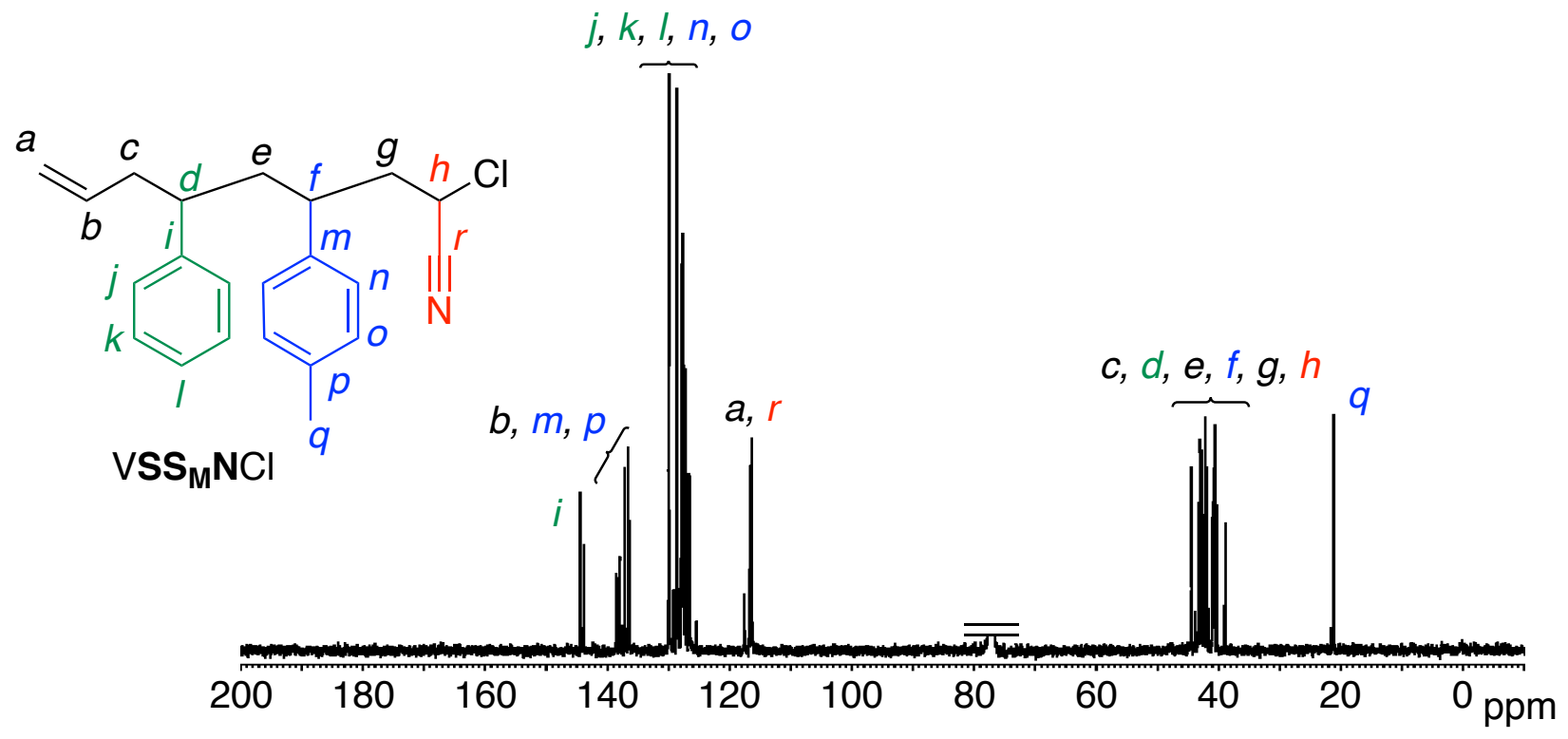

Figure S3. ${ }^{13} \mathrm{C}$ NMR spectrum $\left(\mathrm{CDCl}_{3}, 25{ }^{\circ} \mathrm{C}\right)$ of $\mathrm{VSS}_{\mathbf{M}} \mathrm{NCl}$.

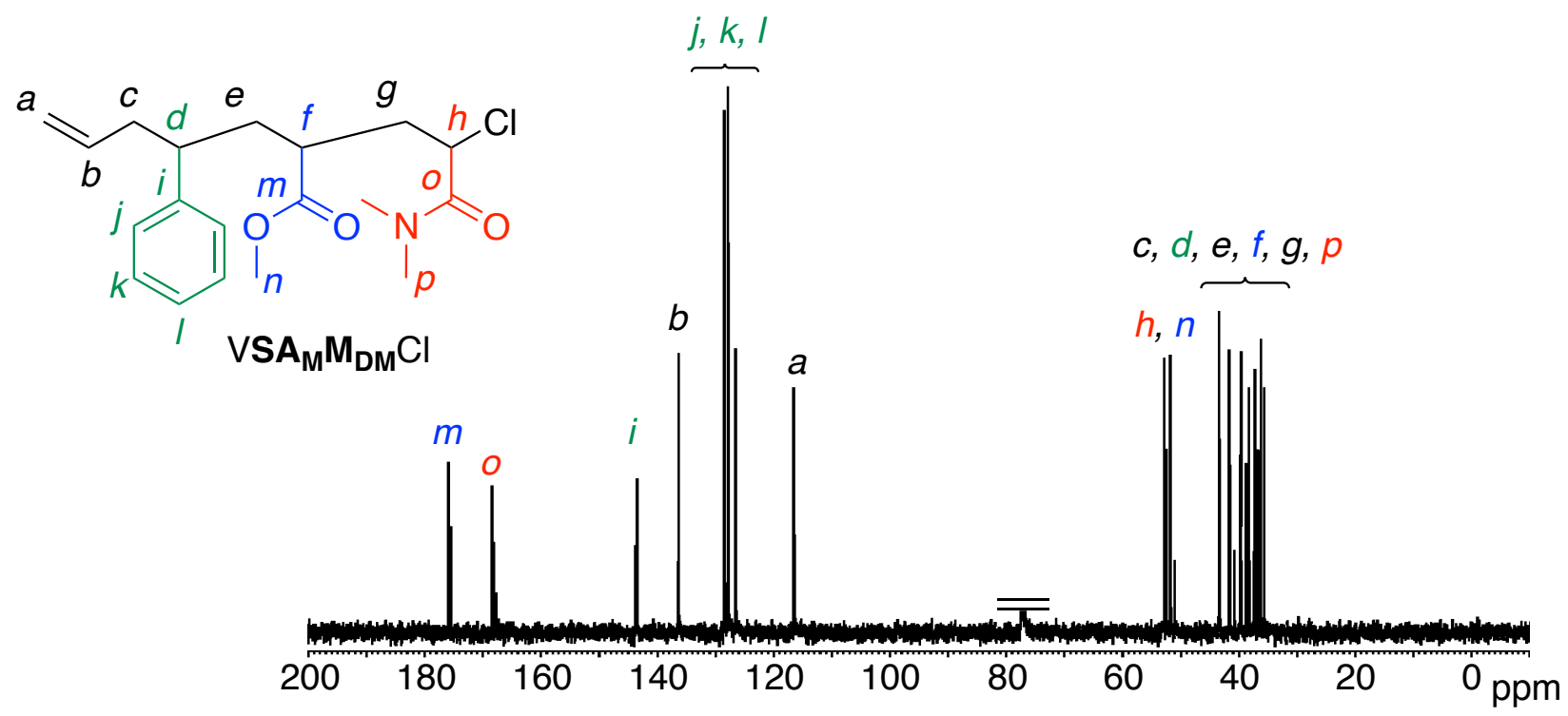

Figure S4. ${ }^{13} \mathrm{C}$ NMR spectrum $\left(\mathrm{CDCl}_{3}, 25{ }^{\circ} \mathrm{C}\right)$ of $\mathrm{VS}_{\mathbf{M}} \mathbf{A}_{\mathbf{M}} \mathbf{M}_{\mathbf{D M}} \mathrm{Cl}$. 


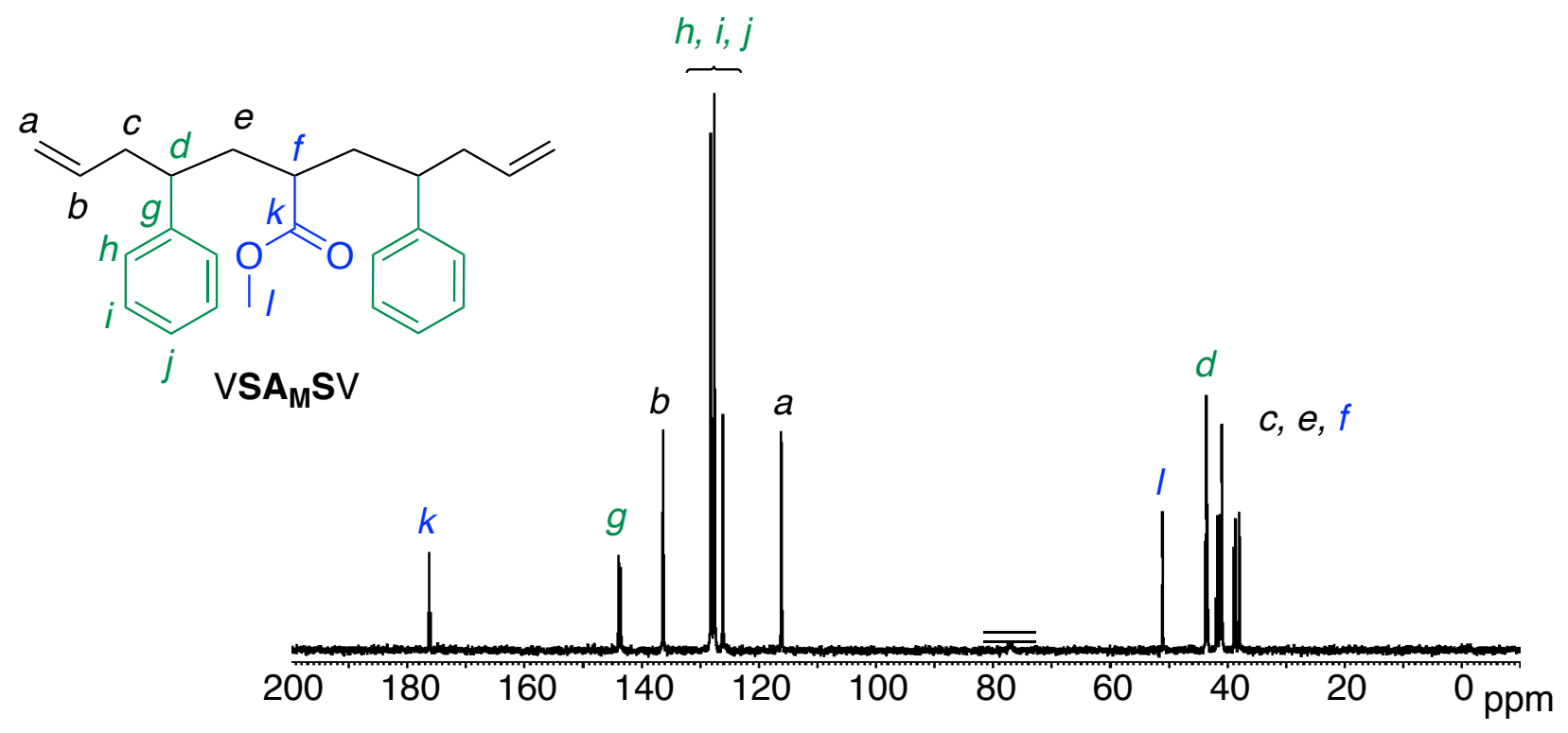

Figure S5. ${ }^{13} \mathrm{C}$ NMR spectrum $\left(\mathrm{CDCl}_{3}, 25{ }^{\circ} \mathrm{C}\right)$ of $\mathrm{VSA} \mathbf{A}_{\mathbf{M}} \mathbf{S V}$. 


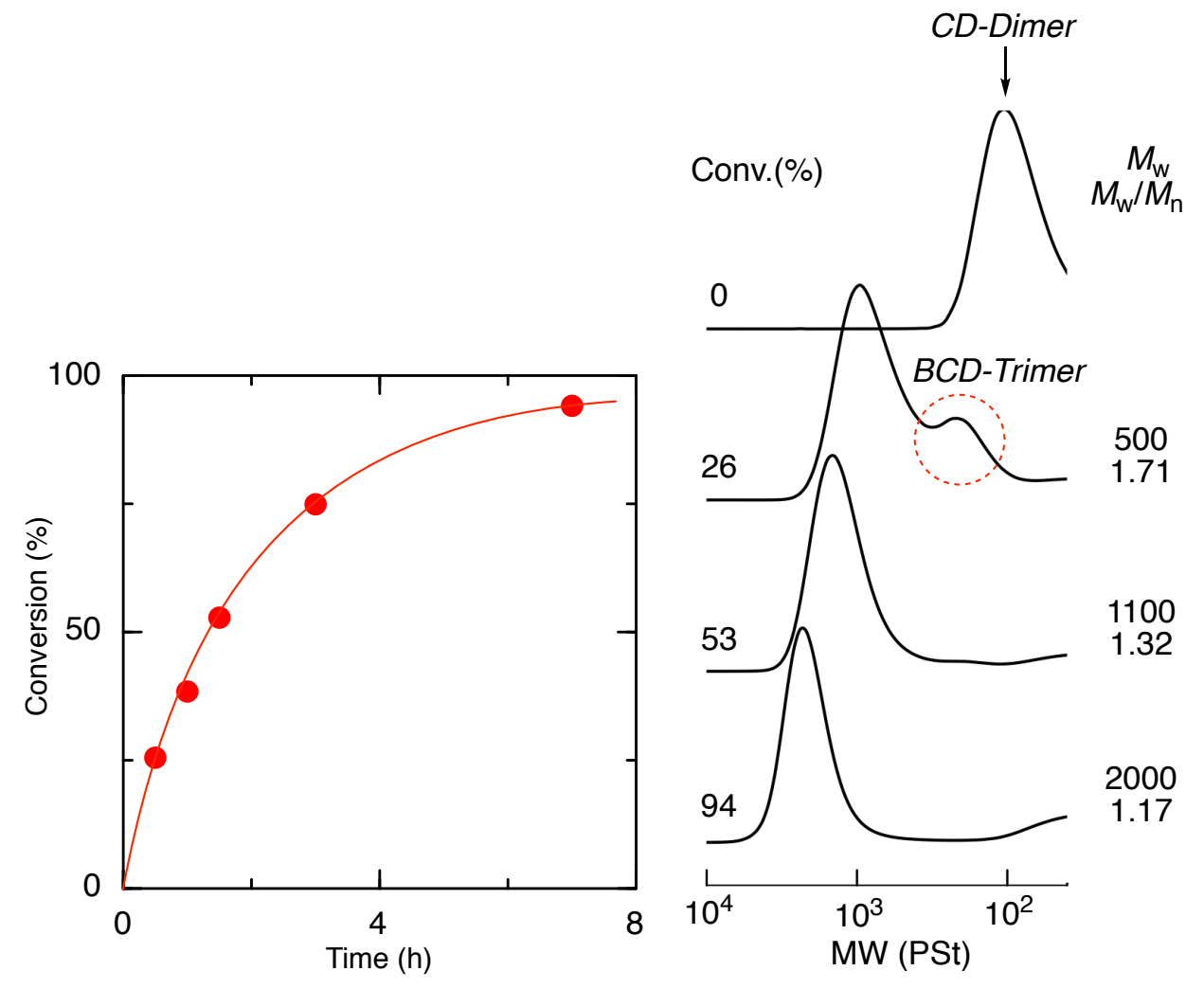

Figure S6. Living cationic polymerization of styrene with $\mathrm{ClS} \mathbf{S}_{\mathbf{M}} \mathbf{A}_{\mathbf{M}} \mathrm{Cl} / \mathrm{SnCl}_{4} / n \mathrm{Bu}_{4} \mathrm{NCl}$ in $\mathrm{CH}_{2} \mathrm{Cl}_{2}$ at $-40{ }^{\circ} \mathrm{C}$ : $[\text { styrene }]_{0} /\left[\mathrm{ClS}_{\mathbf{M}} \mathbf{A}_{\mathbf{M}} \mathrm{Cl}\right]_{0} /\left[\mathrm{SnCl}_{4}\right]_{0} /\left[n \mathrm{Bu}_{4} \mathrm{NCl}\right]_{0}=500 / 25 / 100 / 40 \mathrm{mM}$.
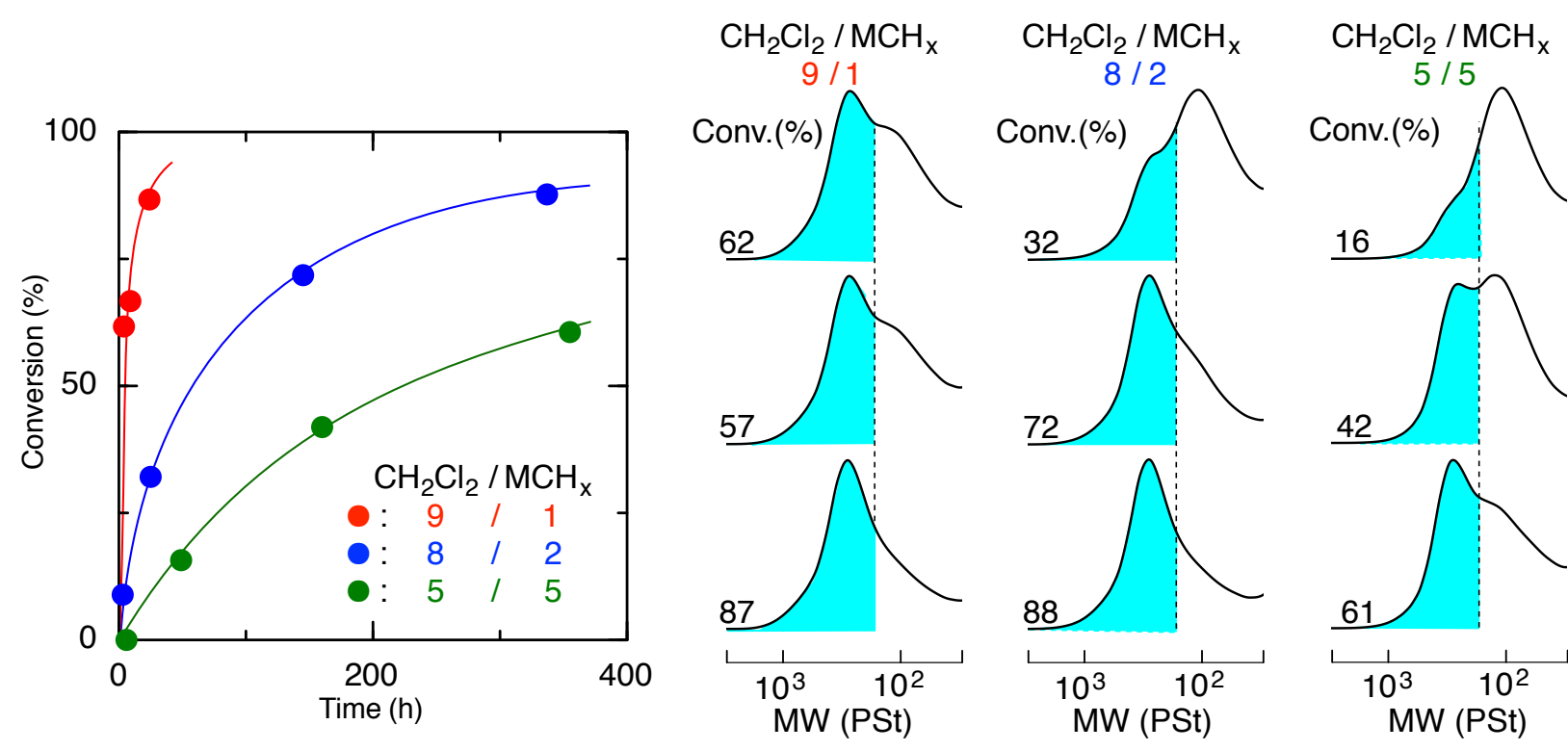

Figure S7. Effect of solvents on cationic single styrene addition to $\mathrm{ClS}_{\mathbf{M}} \mathbf{A}_{\mathbf{M}} \mathrm{Cl}$ with $\mathrm{SnCl}_{4} / n \mathrm{Bu}_{4} \mathrm{NCl}$ in $\mathrm{CH}_{2} \mathrm{Cl}_{2}$ at $-40{ }^{\circ} \mathrm{C}$ : [styrene $]_{0} /\left[\mathrm{Cl} \mathbf{S}_{\mathbf{M}} \mathbf{A}_{\mathbf{M}} \mathrm{Cl}_{0} /\left[\mathrm{SnCl}_{4}\right]_{0} /\left[n \mathrm{Bu}_{4} \mathrm{NCl}_{0}=\right.\right.$ $550 / 500 / 50 / 60 \mathrm{mM}$. 

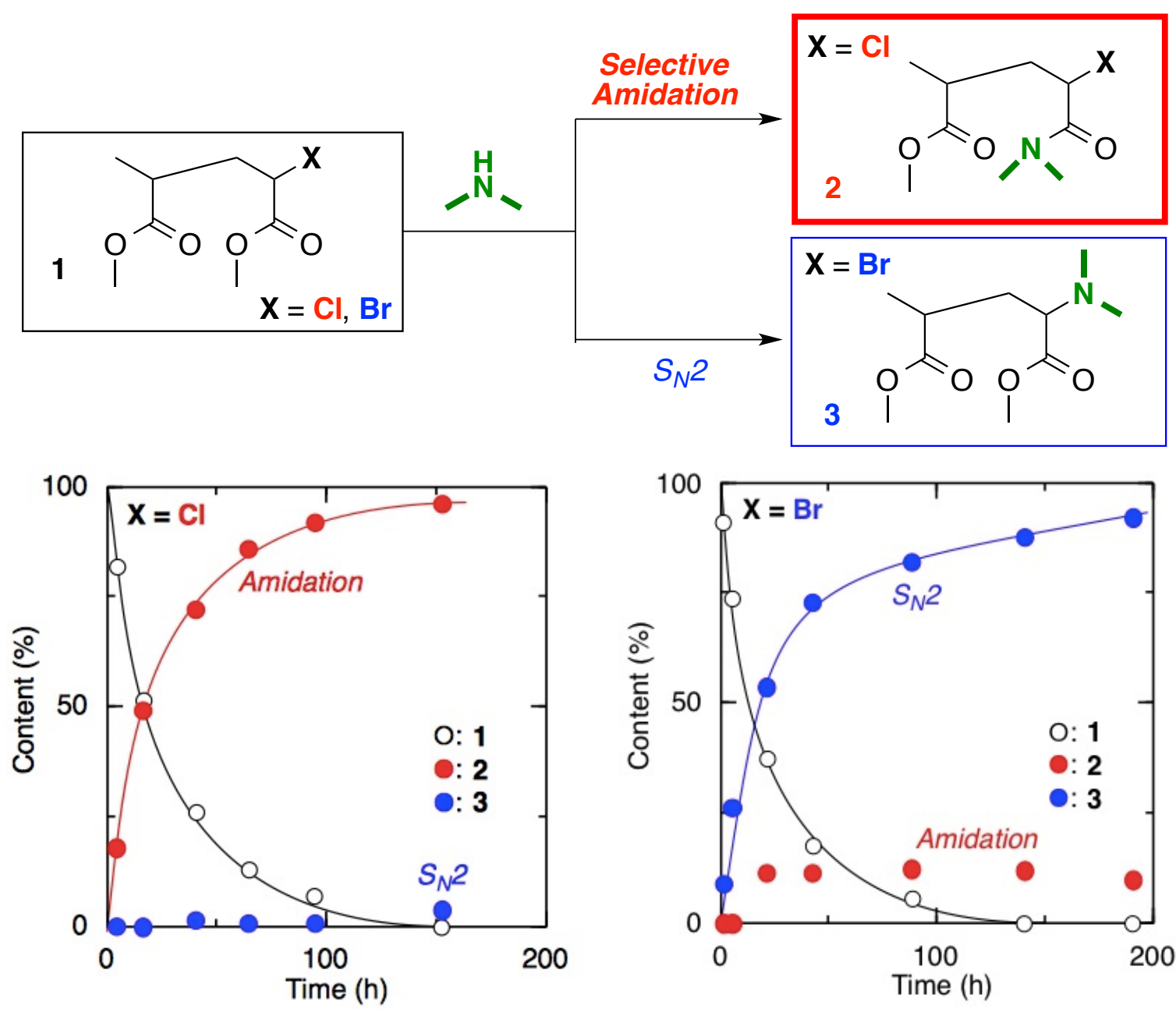

Figure S8. Model reactions between $\mathbf{A}_{\mathbf{M}} \mathbf{A}_{\mathbf{M}} \mathrm{Cl}$ or $\mathbf{A}_{\mathbf{M}} \mathbf{A}_{\mathbf{M}} \mathrm{Br}$ and dimethylamine in $\mathrm{MeOH}$ at $0{ }^{\circ} \mathrm{C}$ $\left[\mathbf{A}_{\mathbf{M}} \mathbf{A}_{\mathbf{M}} \mathrm{X}\right]_{0} /\left[\mathrm{Me}_{2} \mathrm{NH}\right]_{0}=130 / 1950 \mathrm{mM}$. 


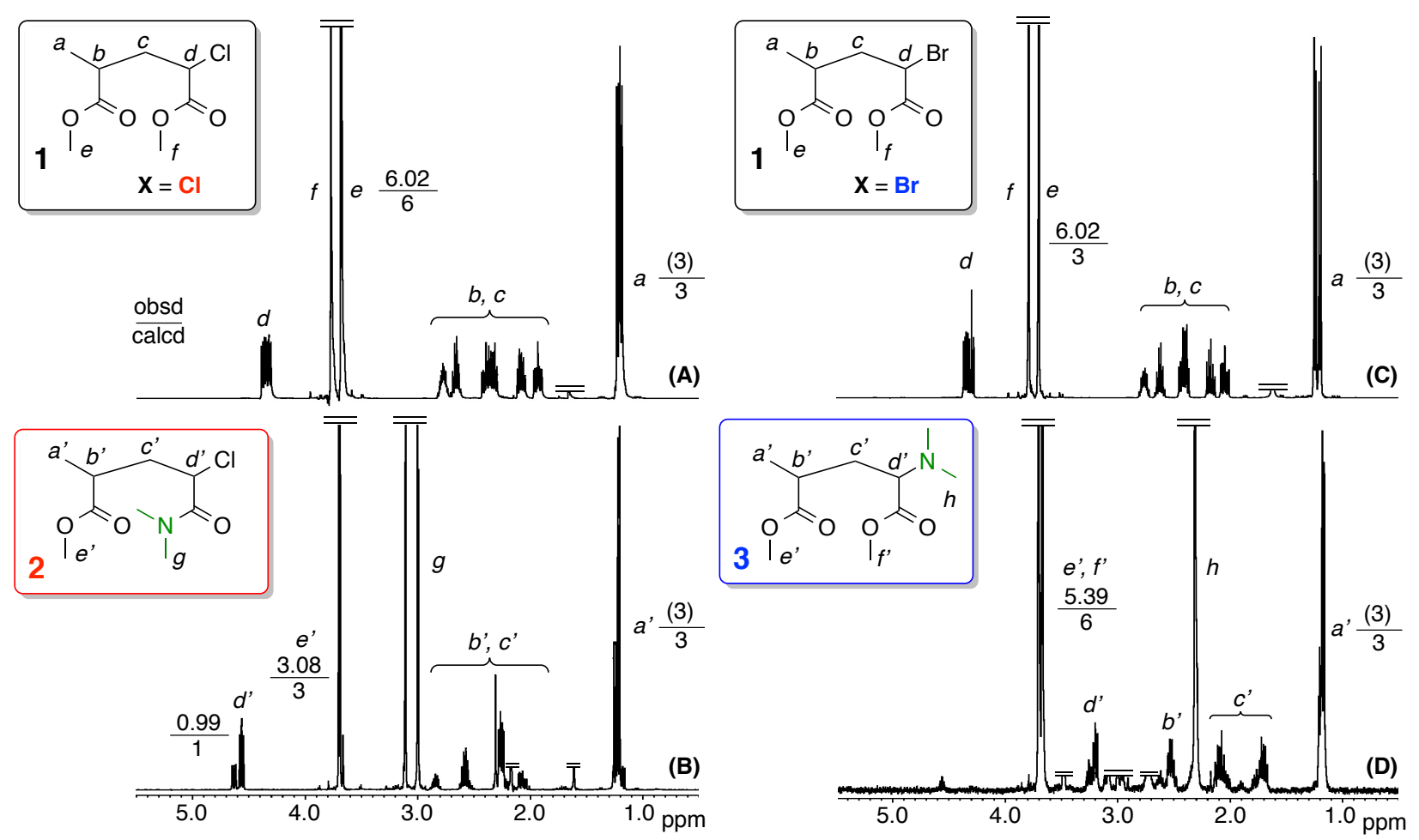

Figure S9. ${ }^{1} \mathrm{H} \mathrm{NMR}$ spectra $\left(\mathrm{CDCl}_{3}, 25{ }^{\circ} \mathrm{C}\right)$ of $\mathbf{A}_{\mathbf{M}} \mathbf{A}_{\mathbf{M}} \mathrm{Cl}$ (A), main product obtained from $\mathbf{A}_{\mathbf{M}} \mathbf{A}_{\mathbf{M}} \mathrm{Cl}$ and $\mathrm{Me}_{2} \mathrm{NH}(\mathrm{B}), \mathbf{A}_{\mathbf{M}} \mathbf{A}_{\mathbf{M}} \mathrm{Br}$ (C), and main product obtained from $\mathbf{A}_{\mathbf{M}} \mathbf{A}_{\mathbf{M}} \mathrm{Br}$ and $\mathrm{Me}_{2} \mathrm{NH}$ (D). 


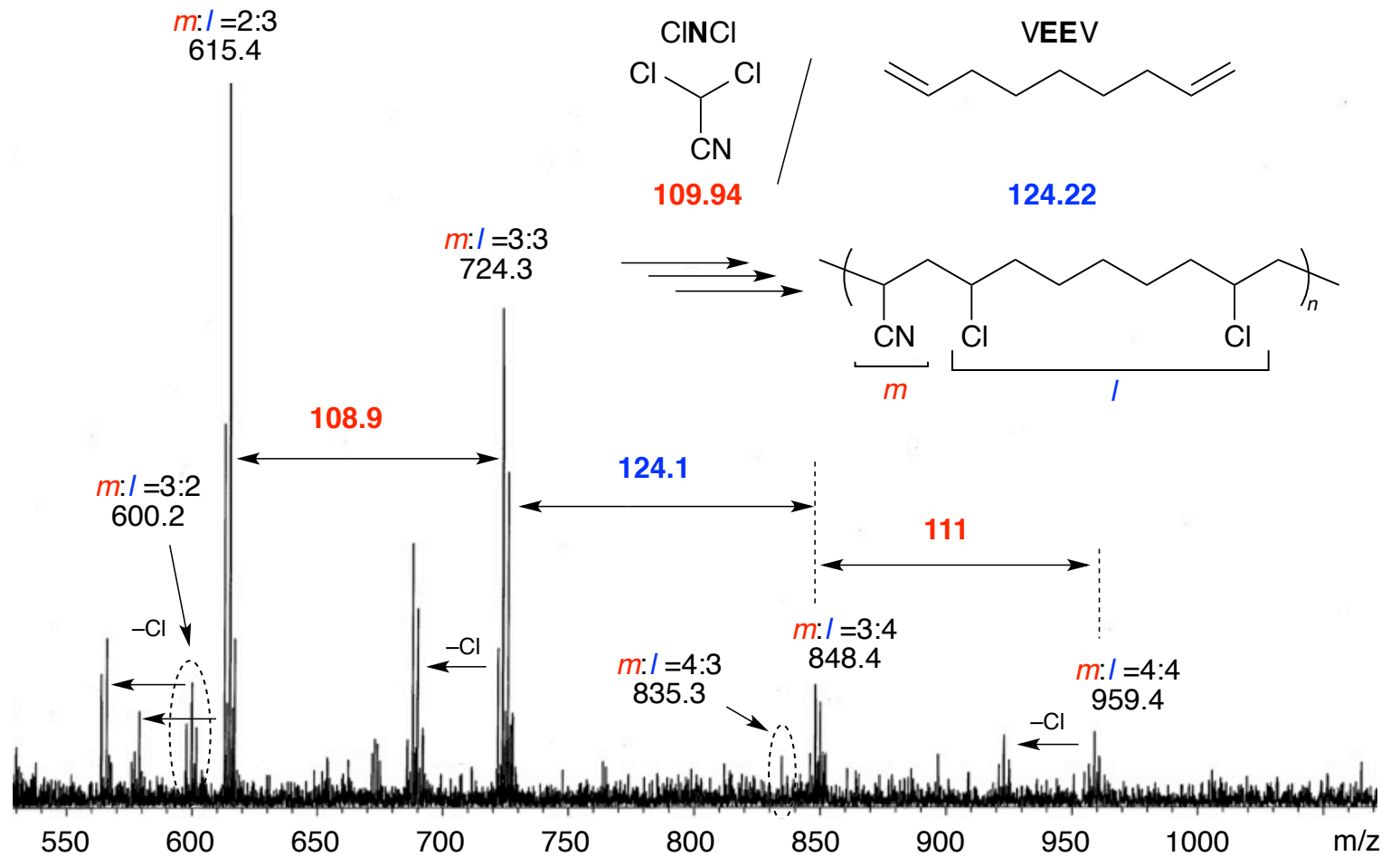

Figure S10. MALDI-TOF-MS spectrum of polymers obtained by step-growth radical polymerization of between $\mathrm{VEEV}$ and $\mathrm{ClNCl}$ using $\mathrm{CuCl} /$ bpy in toluene at $100{ }^{\circ} \mathrm{C}$ (entry 5 in Table S2).

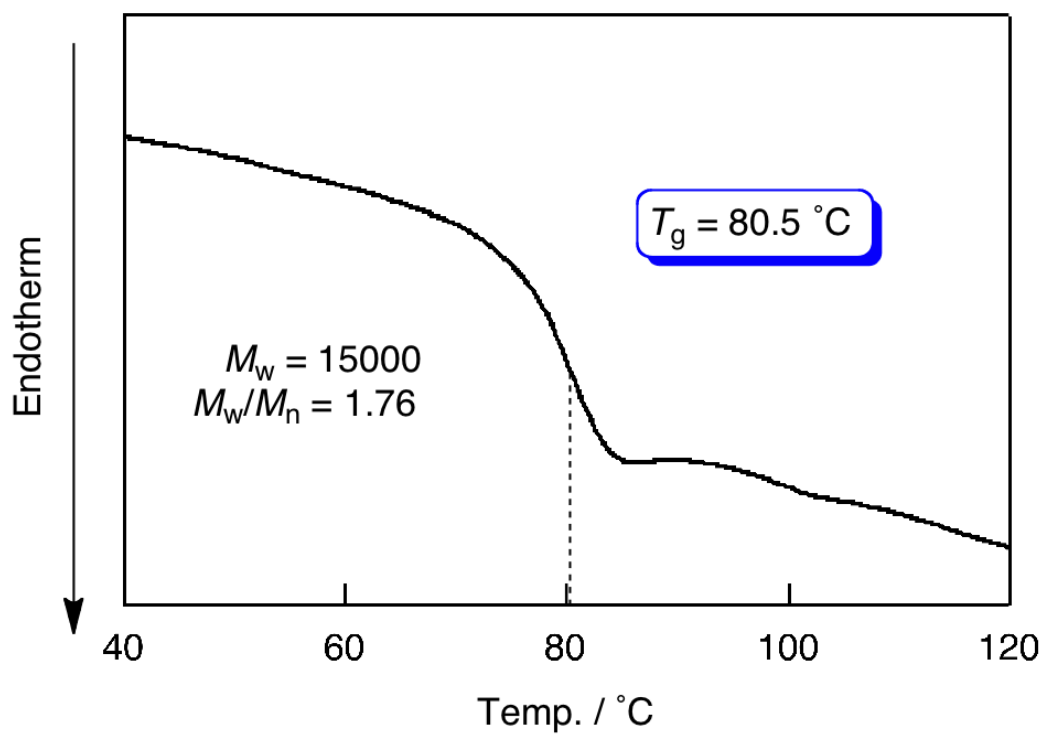

Figure S11. DSC curve of $\left(\mathbf{V}_{\mathbf{c}} \mathbf{S} \mathbf{A}_{\mathbf{M}} \mathbf{S} \mathbf{V}_{\mathbf{c}} \mathbf{N}\right)_{n}\left(M_{\mathrm{w}}=15000, M_{\mathrm{w}} / M_{\mathrm{n}}=1.76\right)$ obtained with $\mathrm{CuCl} / \mathrm{bpy}$ in toluene at $100{ }^{\circ} \mathrm{C}$ followed by fractionation by preparative SEC. 